\title{
SAÚDE PRIVADA E A MEDICINA BASEADA EM EVIDÊNCIAS COMO FONTE DE CRITÉRIOS ORIENTADORES DA INTERVENÇÃO JUDICIAL
}

\author{
PRIVATE HEALTHCARE AND EVIDENCE BASED MEDICINE \\ AS A SOURCE OF GUIDELINES FOR JUDICIAL INTERVENTION
}

\author{
EDUARDO ROCHA DIAS ${ }^{1}$ \\ UINIE CAMINHA ${ }^{2}$
}

\begin{abstract}
RESUMO: O objetivo do presente trabalho é analisar a utilização da chamada medicina baseada em evidência como parâmetro para a intervenção judicial no mercado de saúde, tanto na esfera pública como na privada. Para tanto, analisa-se o conteúdo do direito fundamental à saúde, a prestação de serviços de saúde por entres privados e ainda os riscos de desequilíbrio ocasionado por uma intervenção judicial em contratos de prestação de serviços de saúde ou nos tratamentos oferecidos pelo sistema público, sem um critério objetivo. Por fim, sugere-se a utilização da medicina baseada em evidência como possível critério para essa intervenção.

PALAVRAS-CHAVE: Direito à Saúde; Intervenção Judicial; Medicina Baseada em Evidências.
\end{abstract}

\begin{abstract}
The scope of this essay is to analyse de use of the so called "evidence based medicine" as a guideline for judicial intervention in health care market, in public and private areas. In this sense, the content of fundamental right to health care provided by Brazilian Federal Constitution; as well as the rendering of health care services by private enterpreneurs; and specially the risk of unbalance arisen from a judicial intervention in private contracts or in the treatments offered by the public health system, without an objective guideline are analysed. The use of the so called "evidence based medicine" is suggested as a possible guideline for such intervention. KEYWORDS: Right to Healthcare; Judicial Intervention; Evidence-based Medicine.

SUMÁRIO: Introdução; 1. O Direito Fundamental à Saúde na Ordem Jurídicoprivada; 2. A Saúde Privada no Brasil e os Riscos de uma Inadequada Intervenção Judicial; 3. A Medicina Baseada em Evidências e sua Utilização como Fonte de Critérios para a Atuação do Judiciário; Conclusões; Referências.
\end{abstract}

\footnotetext{
Artigo recebido em 01.11.2014. Pareceres emitidos em 03.03.2015, 05.03.2015 e 23.04.2015.

Artigo aceito para publicação em 30.06.2015.

${ }^{1}$ Doutor em Direito pela Universidade de Lisboa. Professor do Programa de Pós-Graduação em Direito da Universidade de Fortaleza. Procurador Federal.eduardordias@hotmail.com

${ }^{2}$ Doutora em Direito pela Universidade de São Paulo. Professora do Programa de Pós-Graduação em Direito da Universidade de Fortaleza.ucaminha@gmail.com
} 
SUMMARY: Introduction; 1. Fundamental Right to Healthcare and Private Law;

2. Private Healthcare in Brazil and the Risks of na Inadequate Judicial Intervention;

3. Evidence-based Medicine as a Source of Guidelines for Judicial Review; Conclusions; References.

\section{INTRODUÇÃO}

O objetivo do presente trabalho é analisar a utilização da chamada medicina baseada em evidências como parâmetro para a intervenção judicial no mercado de saúde, tanto na esfera pública como na privada.

O tema da judicialização da saúde não é novo e vem já há algum tempo despertando a atenção da doutrina ${ }^{3}$ e do próprio Poder Judiciário ${ }^{4}$. Consagrado como direito fundamental na Constituição de 1988, conforme previsões de

\footnotetext{
${ }^{3}$ Sem uma pretensão de exaustividade, mencionem-se apenas as seguintes obras: SCAFF, Fernando Facury; NUNES, José Avelãs. Os Tribunais e o Direito à Saúde. Porto Alegre: Livraria do Advogado, 2011; MILANEZ, Daniela. O Direito à Saúde: uma análise comparativa da intervenção judicial. In: Revista de Direito Administrativo, $n^{\circ}$ 237, p. 197-221, jul./set. 2004; SARLET, Ingo Wolfgang. Algumas Considerações em Torno do Conteúdo, Eficácia e Efetividade do Direito à Saúde na Constituição de 1988. In: Interesse Público, v. 3, nº 12, p. 91-107, out./dez. 2001; DIAS DE CASTRO, José Augusto. A Questão do Direito Fundamental à Saúde sob a Ótica da Análise Econômica do Direito. In: Revista de Direito Público da Economia, ano 6, n² 21, p. 149-158, jan./mar. 2008; WANG, Daniel. Courts as Healthcare Policy-makers: the problem, the responses to the problem and the problem in the responses. São Paulo Law School of Fundação Getúlio Vargas - Direito GV. Research Paper Series - Legal Studies. Paper $n^{\circ} 75$. In http://biblioteca digital.fgv.br/dspace/bitstream/handle/10438/11198/RPS_75_final.pdf?sequence=1. Acesso em: 20 abr. 2014.

${ }^{4}$ Mencione-se a audiência pública realizada no Supremo Tribunal Federal entre abril e maio de 2009, na qual se ouviram especialistas das mais diversas áreas visando obter subsídios para a atuação da Corte em ações envolvendo o acesso a prestações na área de saúde. Em decorrência da mencionada audiência pública, o Conselho Nacional de Justiça - CNJ, órgão de controle da atuação administrativa e financeira do Poder Judiciário, editou a Recomendação 31 , de 30 de março de 2010, exortando Tribunais de Justiça Estaduais e Tribunais Regionais Federais a celebrar convênios que objetivem disponibilizar apoio técnico composto por médicos e farmacêuticos para auxiliar os magistrados na formação de um juízo de valor quanto à apreciação das questões clínicas apresentadas pelas partes das ações relativas à saúde, observadas as peculiaridades regionais. Também se pediu aos tribunais, por meio das respectivas corregedorias, que orientem os magistrados, dentre outras providências, a procurar instruir as ações em que atuem, tanto quanto possível, com relatórios médicos, com descrição da doença, inclusive CID, contendo prescrição de medicamentos, com denominação genérica ou princípio ativo, produtos, órteses, próteses e insumos em geral, com posologia exata, evitem autorizar o fornecimento de medicamentos ainda não registrados pela ANVISA, ou em fase experimental, ressalvadas as exceções expressamente previstas em lei, e ouçam, quando possível, preferencialmente por meio eletrônico, os gestores, antes da apreciação de medidas de urgência. Ainda dentre as medidas adotadas pelo CNJ, houve a instituição do Fórum Nacional do Judiciário para monitoramento e resolução das demandas de assistência à Saúde - Fórum da Saúde, por meio da sua Resolução 107, de 6 de abril de 2010. O referido Fórum ampliou posteriormente sua área de atuação para incluir a saúde suplementar e as ações judiciais envolvendo relações de consumo. Posteriormente, foi editada a Recomendação 36, de 12 de julho de 2011, específica para as demandas judiciais envolvendo a saúde suplementar. Nesta última, também se recomenda aos Tribunais de Justiça e aos Tribunais Regionais Federais a celebração de convênios que objetivem disponibilizar apoio técnico sem ônus para os Tribunais, composto por médicos e farmacêuticos, que auxilie os magistrados "na formação de um juízo de valor quanto à apreciação das questões clínicas apresentadas pelas partes".
} 
seus arts. $6^{\circ}$ e 196 e seguintes, o acesso à saúde é estudado, sobretudo, como tarefa imposta ao Estado, ou seja, como dever que lhe incumbe, o que enseja relações jurídicas bilaterais nas quais o indivíduo pode vir a ser credor de prestações do poder público. A discussão em torno da judicialização envolve, sob a perspectiva da saúde pública, os temas da "reserva do possível", ante as restrições orçamentárias, e da definição dos limites para intervenção do Judiciário.

Não obstante, a própria Constituição prevê, no caput de seu art. 199, que a assistência à saúde é livre à iniciativa privada, podendo instituições particulares integrar de forma complementar o serviço público de saúde, bem como atuar de forma suplementar a este, oferecendo prestações a serem adquiridas pelos indivíduos com seus próprios recursos.

A prestação privada de serviços de saúde tem relevância pública, na forma do art. 197 da Constituição, atuando o Estado como regulador e fiscalizador. Neste caso, mostra-se evidente o estabelecimento de relações triangulares, em que, além do Estado e dos indivíduos que buscarão serviços e prestações na área de saúde, comparecem sujeitos privados que prestam os mencionados serviços, também detentores de direitos fundamentais, decorrentes da livre iniciativa.

É sob a perspectiva da prestação privada de serviços de saúde que se pretende abordar, neste estudo, o tema da intervenção judicial, buscando identificar, inicialmente, o alcance e a abrangência do direito fundamental à saúde, na perspectiva privada. Em seguida, se buscará examinar como a saúde privada está disciplinada, no Brasil, e como uma inadequada intervenção judicial pode vir a afetá-la, desequilibrando a equação financeira em que se baseia e a distribuição dos custos entre os sujeitos envolvidos. Por fim, serão efetuadas algumas considerações sobre a abordagem conhecida como medicina baseada em evidências (evidence based medicine) e sobre suas potenciais virtudes como fonte de critérios científicos para a incorporação de tratamentos e medicamentos, o que pode conduzir a decisões judiciais mais adequadas e racionais.

O presente estudo parte da perspectiva metodológica de que o direito à saúde constitui posição subjetiva que deve ser efetivada, obrigando agentes públicos e privados, dada sua clara vinculação ao direito à vida e à dignidade da pessoa. Mas tal premissa não pode desconsiderar, sobretudo na saúde privada suplementar, que há uma equação financeira subjacente à prestação de serviços de saúde pela iniciativa privada e que os custos de tal prestação são parte do risco empresarial do empresário que atua nesse ramo ${ }^{5}$.

\footnotetext{
${ }^{5}$ Também no âmbito dos sistemas públicos de saúde a preocupação com o equilíbrio financeiro, ante a limitação dos recursos públicos, deve balizar a atuação do legislador e do Judiciário. Nesse sentido, AICARDI, Nicola. La Sanità. In: Trattato de Diritto Amministrativo - Diritto Amministrativo Speciale, Tomo Primo. Milão: Giuffrè, 2003, p. 630-631.
} 
Apesar de não se adotar aqui exclusivamente uma abordagem ancorada na chamada análise econômica do direito ${ }^{6}$, algumas de suas premissas serão lavadas em conta. Considerações relacionadas com os custos dos direitos, para a sociedade e para os agentes privados, no intuito de examinar as consequências decorrentes da intervenção judicial podem e devem ser levadas em conta.

Isso visa a, exatamente, evitar decisões que não atentem, por exemplo, para o fato de que, se o direito à saúde puder ser tutelado por meio de duas medidas, ambas igualmente eficientes do ponto de vista terapêutico, mas uma menos custosa que a outra, será esta que propiciará que mais recursos sejam aplicados em favor de outros usuários, onerando menos o sistema público de saúde ou o plano ou seguro de saúde privado, e tornando mais eficiente a alocação de recursos no aludido setor. Da mesma maneira, conhecimentos sobre seleção adversa e risco moral, assim como de externalidades contratuais podem trazer decisões mais eficientes para a sociedade de uma forma geral, além de buscar o respeito aos contratos validamente estipulados.

São estas a racionalidade e a razoabilidade que se defende e devem ser buscadas nas decisões judiciais, e para as quais a medicina baseada em evidências parece contribuir em larga medida.

\section{O DIREITO FUNDAMENTAL À SAÚDE NA ORDEM JURÍDICO-PRIVADA}

O reconhecimento e a tutela do direito à saúde revelam a complexidade do papel dos direitos fundamentais nas sociedades contemporâneas e a multifuncionalidade que se Ihes empresta, resultado da também complexa posição da pessoa na coletividade.

É de se destacar, inicialmente, uma dimensão subjetiva para referida posição jurídica, como um direito individual, decorrente da tutela da vida, ${ }^{7}$

\footnotetext{
${ }^{6}$ Por "análise econômica do direito", adaptação da expressão inglesa Law and Economics, que se tornou famosa a partir da obra clássica de mesmo título de Richard Posner, datada de 1958, se entende a abordagem teórica que busca incutir no direito a preocupação da economia de que os recursos são escassos e as necessidades são infinitas, devendo ser buscada a maior eficiência possível na alocação de tais recursos. Nesse sentido, DIAS DE CASTRO, José Augusto. A Questão do Direito Fundamental à Saúde sob a Ótica da Análise Econômica do Direito. In: Revista de Direito Público da Economia, ano 6, n² 21, jan./mar. 2008, p. 150.

${ }^{7}$ No Brasil, o STF já se manifestou nesse sentido, em agravo regimental no Recurso Extraordinário 271.286-RS, relatado pelo Ministro Celso de Mello. Tratava-se, no caso, de recurso manifestado pelo Município de Porto Alegre ante a decisão proferida contra ele e contra o Estado do Rio Grande do Sul, que os obrigou a fornecer gratuitamente medicação contra o vírus HIV a pessoas carentes. Considerou a Corte Suprema brasileira que o direito público subjetivo à saúde representa prerrogativa jurídica indisponível, assegurada à generalidade das pessoas pela própria Constituição em seu artigo 196, traduzindo bem jurídico constitucionalmente tutelado, por cuja integridade deve velar, de maneira responsável, o Poder Público, a quem incumbe formular - e implementar - políticas sociais e econômicas idôneas que visem a garantir, aos cidadãos, inclusive àqueles portadores do vírus HIV, o acesso universal e igualitário à assistência farmacêutica e médicohospitalar. Considerou-se que o direito à saúde - além de qualificar-se como direito fundamental que assiste a todas as pessoas - representa conseqüência constitucional indissociável do direito à vida. Foi reconhecido que "o Poder Público, qualquer que seja a esfera institucional de sua
} 
relativo à participação nas prestações estatais, visando a alcançar o bem-estar físico e mental. ${ }^{8}$ Parte-se aqui da compreensão de que cabe ao Estado, na maior parte das sociedades contemporâneas, um papel preponderante no atendimento à saúde da população.

Há também uma dimensão objetiva do direito à saúde, como um direito fundamental social, que impõe ao Estado as obrigações de: a) editar normas que criem as condições materiais e institucionais para seu exercício; b) proteger o indivíduo contra agressões de terceiros.

A própria definição do que é a saúde, como bem merecedor de proteção, já se mostra uma questão problemática. Recorre-se com frequência à conceituação empregada pela Organização Mundial de Saúde, no Preâmbulo de sua Constituição, datada de 1946: "um estado de completo bem-estar físico, psíquico e social e não apenas a ausência de doença ou enfermidade". Malgrado o caráter algo ambíguo e vago de referida fórmula, ela deve ser utilizada em virtude de constar de uma convenção internacional de que Brasil é signatário, vinculando o Estado brasileiro. Mas é possível afirmar que dificilmente alguém poderá se encontrar em tal estado de "completo bemestar", e que é mesmo mais factível predicar que a saúde, em vez de um estado de "perfeição" pouco realista, é uma condição em equilíbrio variável. ${ }^{9}$ Nela se identificam uma dimensão intrínseca (presença, limitação ou ausência de capacidades vitais e, no limite, a antítese entre vida e morte) e uma dimensão instrumental (uma condição para a vida em liberdade, uma vez que a sua ausência priva a pessoa da capacidade de decidir e de agir, confiando a sua sorte a poderes que lhe são exteriores). ${ }^{10}$

Ao longo da História, diversas foram as atitudes do Poder Público diante da saúde. ${ }^{11}$ Pode-se afirmar que hoje, superada uma visão individualista e absenteísta no tocante à sua promoção, ${ }^{12}$ a saúde é considerada, inicialmente,

atuação no plano da organização federativa brasileira, não pode mostrar-se indiferente ao problema da saúde da população, sob pena de incidir, ainda que por censurável omissão, em grave comportamento inconstitucional".

${ }^{8}$ CORREIA, Sérvulo. Introdução ao Direito da Saúde. In: AAVV. Direito da Saúde e Bioética. Lisboa: Lex, 1991. p. 48; CANOTILHO. Direito Constitucional e Teoria da Constituição. 7. ed., Coimbra: Livraria Almedina, 2003, p. 476-477.

${ }^{9}$ Referindo-se à saúde como um "ponto de equilíbrio", de caráter relativo, ou como uma situação a ser atingida e preservada, examinar AUBY, Jean-Marie (Le Droit de la Santé. Paris: Presses Universitaires de France, 1981, p. 11-12). O autor defende a necessidade de se evitar concepções excessivamente abrangentes para a saúde, que teriam como consequência dar a ela uma dimensão considerável e pouco operativa; no entanto, reconhece que, a par de uma situação individual, a saúde é também um fenômeno social.

${ }^{10}$ BERLINGUER, Giovanni. Bioética Cotidiana. Brasília: Editora da UNB, 2004, p. 211-212.

${ }^{11}$ Para uma visão geral de tais atitudes, examinar GOMES, Carla Amado (Defesa da Saúde Pública vs. Liberdade Individual: casos da vida de um médico de saúde pública. Lisboa: Associação Académica da Faculdade de Direito de Lisboa, 1999, p. 5 e seg.) e BERLINGUER, Giovanni (Bioética Cotidiana. Brasília: Editora da UNB, 2004, p. 213 e seg.).

${ }^{12}$ LAUBADĖRE, André de; VENEZIA, Jean-Claude (Traité de Droit Administratif, v. 3. Paris: Libr. Generale de Droit e de Jurisprudence, 1993, p. 248) lembram que, de início e de uma forma geral, as intervenções estatais no domínio da saúde refletiam uma concepção individualista, segundo a 
um bem coletivo, o que leva à afirmação de uma dimensão agressiva ou policial de intervenção do Estado, destinada a protegê-la, plasmada, por exemplo, na prática de atos como a emissão de autorizações para funcionamento de estabelecimentos ou exercício de certas atividades, imposição de condutas e deveres aos particulares e aplicação de sanções. Há também uma dimensão organizativa ou procedimental; e uma dimensão prestacional, à qual corresponde um direito à saúde, de cariz subjetivo. Tal dimensão subjetiva, porém, tem não apenas uma vertente positiva, mas também uma vertente negativa, consistente no direito de exigir do Estado e de terceiros que se abstenham de qualquer ato que prejudique a saúde. ${ }^{13}$

O direito à saúde inclui ainda uma liberdade de escolha quanto aos tratamentos a serem adotados ou quanto à recusa de tratamento, quanto à opção pela auto ou pela heterocura, quanto à adoção de terapias tradicionais ou alternativas, dentre outros aspectos. Ou seja, sob a perspectiva individual, ninguém pode ser obrigado a ter sua saúde tratada de determinada maneira. Apesar de ainda incipientes quanto ao conteúdo e vinculação dos profissionais de saúde ou familiares a seus termos, as diretivas antecipadas de vontade oferecem aos pacientes a possibilidade de determinar - mesmo que minimamente, a que tratamentos estão dispostos a se submeter e em que termos permitem a continuação da vida por meios artificiais.

Cabe, ainda, a cada um escolher se será atendido pelo sistema público (SUS) ou, se tiver os meios para efetuar pagamento, pela iniciativa privada. A propósito, mencionem-se decisões do Supremo Tribunal Federal que afastaram

qual a saúde era sobretudo um bem individual, cuja proteção era assegurada por meio de medidas destinadas a impedir que as condutas de cada um criassem riscos à saúde dos outros. Tais medidas eram tradicionalmente referidas como abrangidas pela noção de higiene pública. Posteriormente, passou a prevalecer uma concepção social, que vislumbra a saúde como um bem coletivo, que fundamenta o oferecimento de prestações e o estabelecimento de deveres para os cidadãos. Tais deveres, por sua vez, não se limitam às obrigações clássicas compreendidas na mencionada noção de higiene pública, mas são cada vez mais diversificadas, principalmente no campo da profilaxia, como as vacinações obrigatórias.

${ }^{13}$ GOMES, Carla Amado. Defesa da Saúde Pública vs. Liberdade Individual: casos da vida de um médico de saúde pública. Lisboa: Associação Académica da Faculdade de Direito de Lisboa, 1999, p. 11. MILANEZ, Daniela (O Direito à Saúde: uma análise comparativa da intervenção judicial. In: Revista de Direito Administrativo, $\mathrm{n}^{\circ}$ 237, jul./set. 2004, p. 198 e seg.) menciona que são três as obrigações principais decorrentes do direito à saúde para o Estado: respeitar, proteger e implementar. Pela primeira, proíbe-se qualquer intrusão na vida do indivíduo que possa resultar em diminuição da sua saúde; pela segunda, exige-se que o Estado iniba a ação de terceiros que possa violar ou desrespeitar o direito à saúde; pela terceira, tem-se que o Estado deve fornecer ou facilitar o fornecimento de bens e serviços destinados a suprir as necessidades básicas da sociedade. A obrigação de respeitar possui um conteúdo negativo, que impede ações tendentes a atingir o direito à saúde, podendo originar direitos subjetivos de proteção contra o Estado. A obrigação de proteger tem um conteúdo positivo, já que por ela se demandam ações jurídicas (como a elaboração de normas) e fáticas (criação de organizações, exercício de poder de polícia) destinadas a proteger os cidadãos contra terceiros. A obrigação de implementar tem um conteúdo mais organizativo e procedimental, mas também inclui o oferecimento de prestações. Há maior reticência em se reconhecer uma dimensão subjetiva no tocante aos dois últimos aspectos, que somente estaria presente em situações de urgência e de grave lesão à dignidade da pessoa. 
a tentativa de entes federativos, notadamente Estados e Municípios, de instituir uma cobrança obrigatória de "contribuição" para atendimento à saúde de seus servidores. No RE 573.540/MG e na ADI 3106 se fixou o entendimento de que a Constituição de 1988 não permite a cobrança compulsória dos servidores públicos de contribuição destinada a serviços de saúde, sejam médicos, odontológicos, farmacêuticos ou sociais, mas apenas a cobrança de contribuição para os respectivos sistemas de previdência social, na forma do $\S 1^{\circ}$ do art. 149 da Carta Magna. Também se destacou que somente de forma facultativa e voluntária os servidores poderiam contribuir para custeio de serviços de saúde. Não se deixa de privilegiar, nesse ponto, a autonomia individual para decidir como se dará o atendimento à saúde, se por meio do SUS, se por plano particular escolhido pelo servidor ou se por meio do serviço oferecido pelo ente estatal.

Outro aspecto da perspectiva individual do direito à saúde é o que permite a cada um escolher se tratar ou não, ou, se for se tratar, se adotará terapias tradicionais ou "alternativas", alopatia ou homeopatia e assim por diante.

Em regra, tal vertente do direito à saúde impede qualquer ingerência do Estado e dos outros indivíduos sobre o complexo representado pelo estado físico e psíquico da pessoa, impondo-lhes a abstenção de atos susceptíveis de incidir sobre referido estado sem o consentimento do interessado. ${ }^{14}$ A autodeterminação individual, portanto, tem também reflexos sobre o estado da pessoa, desempenhando papel importante. Essa prerrogativa pode vir a se manifestar como uma liberdade de autodeterminação bioética, em setores que afetam o conjunto biofísico-psíquico da pessoa, como no caso da manifestação de consentimento para uma cirurgia de mudança de sexo ou na doação de órgãos por pessoa viva, por exemplo ${ }^{15}$. Como correlatos do direito à saúde há também: a) um dever meramente objetivo de defesa e promoção da saúde pública como valor ou interesse comunitário, independentemente dos reflexos sobre a saúde de cada um; b) um direito-dever de solidariedade voltado para a defesa e a promoção da saúde própria como condição de defesa e promoção da saúde de todos. ${ }^{16}$

Assim, somente na medida em que o "mau estado de saúde de alguém possa reflectir-se no estado sanitário comunitário é que o Estado pode intervir, impondo determinados comportamentos (ou abstenção deles) ao cidadão doente". ${ }^{17}$ Dentre tais hipóteses, mencionem-se os casos de vacinação

\footnotetext{
${ }^{14}$ AICARDI. La Sanità. In: CASSESE (Coord.). Trattato de Diritto Amministrativo - Diritto Amministrativo Speciale, Tomo Primo. Milão: Giuffrè, 2003, p. 627.

${ }^{15}$ A respeito do assunto, examinar DIAS, Eduardo Rocha. Autodeterminação Individual e Transplante de Órgãos: entre os direitos de personalidade e os direitos fundamentais. In: Joyceane Bezerra de Menezes (org.). Dimensões Jurídicas da Personalidade na Ordem Constitucional Brasileira. Florianópolis: Conceito Editorial, 2010, p. 129-165.

${ }^{16}$ NABAIS, Casalta. O Dever Fundamental de Pagar Impostos. Coimbra: Livraria Almedina, 1998, p. 124, nota 295.

${ }^{17}$ GOMES, Carla Amado. Defesa da Saúde Pública vs. Liberdade Individual: casos da vida de um médico de saúde pública. Lisboa: Associação Académica da Faculdade de Direito de Lisboa, 1999, p. 23.
} 
obrigatória e de tratamento de doenças contagiosas. No caso de pessoas privadas da razão, porém, admite-se a adoção de medidas, como o internamento compulsório, como forma de tutelar a dignidade individual. Aqui não há, necessariamente, reflexos sobre a saúde e o bem-estar dos demais indivíduos, podendo a medida reverter unicamente em benefício da própria pessoa. ${ }^{18}$ Fora de tais hipóteses, que devem ser previstas expressamente em lei, não se admite, em regra, um "dever à saúde" ou um "dever de curar-se". ${ }^{19}$

É lugar comum, na doutrina, reconhecer ao legislador uma maior margem de conformação dos direitos sociais, como o direito à saúde, ante a sua dependência da reserva do possível ou "dos cofres cheios". ${ }^{20}$ Isto é, há de se levar em conta as condições fáticas, de ordem econômica, na determinação do alcance de tal direito. Ademais, este último não é plenamente determinável no plano constitucional, demandando a intervenção concretizadora do legislador. ${ }^{21}$ Importante também é a chamada reserva parlamentar em matéria orçamentária, decorrente do princípio democrático e da separação de poderes, que impõe condicionamentos jurídicos à concretização dos direitos sociais. ${ }^{22}$ Feriria tal princípio a ingerência do Poder Judiciário, sempre que, por meio de decisões para casos insolados, comprometessem a execução do orçamento estipulado, especialmente se se considerar que, ao estipular uma prestação não prevista em orçamento, não há também a determinação de origem dos recursos.

A esse respeito, ponderam Pinheiro e Saddi ${ }^{23}$ :

O Judiciário tem o condão de aumentar o déficit das contas do Estado, sobretudo quando julga sem considerar a extensão no plano econômico, situação que se agigantou especialmente do Supremo Tribunal Federal (STF). O problema parece insolúvel: se, por um lado, é preciso garantir que a justiça seja feita no plano individual, por outro, não se pode chegar ao ponto de falir o Estado (e a sociedade) para tanto.

\footnotetext{
${ }^{18}$ Em Portugal, o internamento compulsório, como medida que restringe a liberdade individual, é medida prevista constitucionalmente, na alínea "h" do artigo 27 da Constituição da República Portuguesa, e há de ser decretado ou confirmado por autoridade judicial competente. A Lei $n^{\circ}$ 36/98, de 24 de julho, por sua vez, "regula o internamento compulsivo dos portadores de anomalia psíquica, designadamente das pessoas com deficiência mental" (artigo $1^{\circ}$ ). No Brasil, o tema não é tratado pela CF/88. Encontra-se, porém, nos artigos $6^{\circ}$ a $8^{\circ}$ da Lei $n^{\circ} 10.216 / 2001$ a submissão do internamento compulsório à reserva de jurisdição.

${ }^{19}$ Levando em conta o artigo 32 , parágrafo $2^{\circ}$, da Constituição italiana, que dispõe que ninguém será obrigado a um determinado tratamento a não ser em virtude de lei, a qual, porém, não pode violar os limites impostos pelo respeito à pessoa humana, examinar AICARDI, Nicola (La Sanità. In: CASSESE (Coord.). Trattato de Diritto Amministrativo - Diritto Amministrativo Speciale, Tomo Primo. Milão: Giuffrè, 2003, p. 628-629).

${ }^{20}$ CANOTILHO. Direito Constitucional e Teoria da Constituição. 7. ed., Coimbra: Livraria Almedina, 2003, p. 480-482.

${ }^{21}$ SARLET. A Eficácia dos Direitos Fundamentais, 3. ed., Porto Alegre: Livraria do Advogado, 2003, p. 297-298.

${ }^{22}$ SARLET. Algumas Considerações em Torno do Conteúdo, Eficácia e Efetividade do Direito à Saúde na Constituição de 1988. In: Interesse Público, v. 3, no 12, out./dez. 2001, p. 103.

${ }^{23}$ PINHEIRO, Armando Castelar; SADDI, Jairo. Direito, Economia e Mercados. Rio de Janeiro: Campus, 2005, p. 5.
} 
A satisfação individual de uma pretensão em juízo, com determinação de aplicação de recursos públicos escassos em uma dada finalidade, pode afetar a satisfação legítima de outras finalidades, gerando os chamados "custos de oportunidade". Tais custos podem ser definidos como aquilo que se deixou de ganhar em "A" por se decidir investir em "B", considerando o que poderia ser obtido a partir de um melhor uso alternativo dos recursos disponíveis. Assim, uma determinação judicial que satisfaça o direito de uma pessoa impõe que se considere os direitos que deixaram de ser satisfeitos caso se tivesse aplicado diferentemente os recursos disponíveis. Isso implica realizar escolhas, raciocínio que não pode deixar de ser feito no âmbito judicial ${ }^{24}$.

É indiscutível, porém, a vinculação dos poderes públicos à sua concretização, por meio de medidas normativas, procedimentais e organizatórias. ${ }^{25}$ Uma vez concretizados, tais direitos conferem aos cidadãos direitos derivados a uma igual participação nas prestações oferecidas, bem como passam a impor ao legislador proibição de retrocesso, que veda a supressão posterior do direito, sem o estabelecimento de alternativas ou compensações e sem a devida motivação. $^{26}$

\footnotetext{
${ }^{24}$ Nesse sentido, examinar WANG, Daniel. A Escassez de Recursos como Limitação para Concretização de Direitos (Comentários a acórdão do STJ). In: Revista de Direito Público da Economia, ano 5, n 20, out./nov. 2007, p. 240-241.

${ }^{25} \mathrm{Na}$ jurisprudência do Supremo Tribunal Federal, cumpre examinar a decisão proferida no Recurso Extraordinário 267.612-RS, Relatado pelo Ministro Celso de Mello, e publicada no Diário de Justiça da União, 23 ago. 2000.

${ }^{26}$ A respeito do princípio do não-retrocesso social, é de se referir a decisão proferida pelo Tribunal Constitucional português no Acórdão no 39/84, em que se reconheceu que, "a partir do momento em que o Estado cumpre (total ou parcialmente) as tarefas constitucionalmente impostas para realizar um direito social, o respeito constitucional deste deixa de consistir (ou deixa de consistir apenas) numa obrigação positiva, para se transformar ou passar também a ser uma obrigação negativa. O Estado, que estava obrigado a actuar para dar satisfação ao direito social, passa a estar obrigado a abster-se de atentar contra a realização dada ao direito social" (ANDRADE, José Carlos Vieira de. O Direito ao Mínimo de Existência Condigna como Direito Fundamental a Prestações Estaduais Positivas: uma decisão singular do Tribunal Constitucional. Anotação ao Acórdão do Tribunal Constitucional $n^{\circ}$ 509/02. Jurisprudência Constitucional, $n^{\circ} 1$, jan./mar. 2004, p. 95). Tratava-se, no caso, de norma que havia revogado boa parte da Lei do Serviço Nacional de Saúde, contrariando, no entender do Tribunal, o direito fundamental à saúde, o qual demanda, para sua concretização, a criação de referido serviço (artigo 64, $n^{\circ} 2$, da CRP). Ressalte-se que a vedação de retrocesso pode dar-se também no tocante aos direitos fundamentais de primeira geração, ou direitos, liberdades e garantias. Na jurisprudência do Conselho Constitucional francês, a propósito, uma das primeiras decisões em que se reconheceu a impossibilidade da ab-rogação de uma lei, por inviabilizar o exercício de um direito fundamental, envolveu justamente uma posição jurídica de referida espécie, no caso a garantia outorgada aos docentes de cursos superiores de se fazerem representar adequadamente nos órgãos diretivos de mencionadas instituições. Examinar, nesse sentido, a decisão $\mathrm{n}^{\circ}$ 83-165 DC, de 20 de janeiro de 1984, referente à lei relativa ao ensino superior (Disponível em: <www.conseil-constitutionnel.fr/decision/1984/83165dc.htm>). Registre-se, por sua vez, o entendimento de NOVAIS, Jorge Reis (O Tribunal Constitucional e os Direitos Sociais - O Direito à Segurança Social. In: Direitos Fundamentais - Trunfos contra a Maioria. Coimbra: Coimbra Editora, 2006, p. 197-198), segundo o qual da reserva do possível decorre a insustentabilidade teórica do princípio da proibição de retrocesso. Não haveria tal proibição nos direitos sociais, nem nos direitos clássicos de liberdade: todos os direitos, segundo
} 
É defensável, por sua vez, o reconhecimento de um direito subjetivo, fundado diretamente na Constituição, a prestações na área da saúde sempre que o indeferimento destas acarretar risco de dano irremediável à vida e à integridade física, o que impõe um sopesamento, no caso concreto, dos bens jurídicos e valores envolvidos. Tais prestações, porém, deverão ater-se aos limites do razoável, o que afasta medidas desnecessárias e inadequadas, consistindo no mínimo indispensável à tutela da vida e da integridade física; ${ }^{27}$ ou seja, se, por um lado, deve-se afastar o entendimento tradicional de que as normas consagradoras do direito fundamental à saúde têm natureza meramente programática, impondo, ao contrário, o reconhecimento do direito aos tratamentos necessários à sua tutela; por outro, há de se ter em conta o papel do legislador na sua concretização, o que impõe considerar uma pluralidade de alternativas e limites, máximos e mínimos, de efetivação. A atuação do legislador deve ser balizada por outros princípios e normas constitucionais, e, em particular, a exigência de equilíbrio nas finanças públicas, impondo-se uma ponderação adequada e razoável ante a limitação dos recursos públicos. ${ }^{28}$

Nesse sentido, no Brasil, o Superior Tribunal de Justiça já decidiu que o Sistema Único de Saúde não é obrigado a pagar tratamento de saúde de alta complexidade no Exterior quando oferece condições para a realização de referido tratamento no País, com equipes médicas e instalações hospitalares adequadas, e por um valor mais baixo do que o do tratamento no estrangeiro, permitindo disponibilizar recursos para o tratamento de outras pessoas. ${ }^{29}$

essa perspectiva, sujeitam-se a retrocessos, que devem, porém, ser justificados, além de atraírem a observância dos princípios que plasmam o Estado de Direito. O que importa é apresentar argumentos que justifiquem a afetação dos direitos fundamentais sociais, considerando-a uma restrição, sujeita a controle tal qual as restrições a direitos fundamentais de liberdade. Devem observar, portanto, os princípios da igualdade, da proibição de excesso, da proteção da confiança e da dignidade da pessoa.

${ }_{27}$ SARLET, Ingo Wolfgang. Algumas Considerações em Torno do Conteúdo, Eficácia e Efetividade do Direito à Saúde na Constituição de 1988. In: Interesse Público, v. 3, nº 12, out./dez. 2001, p. 103-104. Também examinar, do mesmo autor, A Eficácia dos Direitos Fundamentais, 3. ed., Porto Alegre: Livraria do Advogado, 2003, p. 313 e seg.

${ }^{28}$ AICARDI. La Sanità. In: CASSESE (Coord.). Trattato de Diritto Amministrativo - Diritto Amministrativo Speciale, Tomo Primo. Milão: Giuffrè, 2003, p. 630-631.

${ }_{29}$ Decisão do Ministro Edson Vidigal no pedido de Suspensão de Segurança 1.467-DF (2005/ 0016229-5), proferida em 3 de fevereiro de 2005, e publicada no Diário da Justiça da União, 10 fev. 2005 e que também se encontra disponível no sítio <www.stj.gov.br>. Suspendeu-se, por meio de tal decisão, liminar em mandado de segurança que havia determinado ao Secretário de Atenção à Saúde do Ministério da Saúde a liberação de recursos necessários à realização de um transplante de intestino nos Estados Unidos da América. Posteriormente, a Corte Especial do Superior Tribunal de Justiça manteve a suspensão em decisão assim ementada: "Agravo Regimental em Suspensão de Segurança. União. Transplante de Órgão no Exterior. Alegada lesão à ordem administrativa e à saúde pública. Efeito multiplicador. 1. Cabe à Administração fixar e autorizar os tratamentos e remédios que devem ser fornecidos à população, sempre com vistas a garantir a segurança, a eficácia terapêutica e a qualidade necessárias, em território nacional. Questão relativa a matéria de Política Nacional de Saúde. Risco de lesão à ordem pública administrativa configurado. 2. A determinação contra legem que obriga o Estado brasileiro a fornecer as condições 
A Corte Constitucional italiana, na Sentença $151 / 2009^{30}$, esclareceu o alcance do direito à saúde, como compreendendo o direito a receber a cura mais apropriada segundo o melhor conhecimento científico. Tal perspectiva não significa que sempre o melhor tratamento será o mais caro, mas sim que se deve apreciar a sua eficácia terapêutica, o que impõe uma responsabilidade ao profissional da área médica que o prescreve. Tal conclusão terá reflexos importantes na abordagem da medicina baseada em evidências, que tem como preocupação, justamente, aferir a eficácia científica dos tratamentos e medicamentos cuja subministração se pretende efetuar.

\subsection{A Prestação Privada de Serviços de Saúde}

No tocante à prestação privada dos serviços de saúde, a partir da previsão do art. 199, caput, da Constituição, tem-se que se trata de campo aberto para a atuação da iniciativa privada. Esta pode, por meio de convênio ou contrato, participar do sistema público de saúde (SUS), falando-se, nesse caso, de saúde complementar. Pressupõe-se nesse caso a insuficiência da rede pública de saúde, cabendo à rede privada, de forma subsidiária, suprir tal insuficiência ${ }^{31}$. Ou pode explorar, segundo regras de direito privado, e por meio de pagamento efetuado pelos usuários, com seus próprios recursos, serviços de saúde. Trata-se da saúde suplementar.

Organizada com a preocupação de preservar os agentes econômicos que nele atuam, defendendo o mercado ${ }^{32}$, a saúde suplementar integra o campo das atividades econômicas em sentido estrito, o que impõe uma regulamentação que busque preservar a atratividade do seu desempenho por particulares e margens de lucro compatíveis, sob pena de afastar os agentes privados de tal setor, trazendo prejuízos para os consumidores, que seriam privados da oportunidade de optar por ela, não tendo outra alternativa, a não ser a rede pública. Mas não se encontra totalmente entregue às leis do mercado. Nesse sentido, cumpre referir a posição do Supremo Tribunal Federal, manifestada em decisão proferida na ADI 1931-MC ED ${ }^{33}$, no sentido

para que a agravante/requerida faça cirurgia de elevado custo no exterior, havendo quem a faça no país, tem potencial de lesionar a saúde pública, constituindo-se precedente para um número indefinido de outras situações semelhantes. 3. Regimental não provido" (decisão de 16 de fevereiro de 2005, publicada no Diário da Justiça da União, 21 mar. 2005).

${ }^{30} \mathrm{O}$ inteiro teor da decisão pode ser acessado no link: http://www.cortecostituzionale.it/action SchedaPronuncia.do?anno=2009\&numero=151. O caso envolveu a alegação de inconstitucionalidade de lei italiana que tratava da procriação medicamente assistida (Lei 40, de 2004) e que limitava o número de implantação de embriões. Para uma discussão a respeito do assunto, examinar FERRANDO, Gilda. La Donazione dei Gameti in Prospetiva Bioética e nella Legge 40, alla Luce delle Recenti Pronunce Giurisprudenziali. In: Andrea Barenghi (org). Procreazione Assistita e Tutela della Persona. CEDAM: Milão, 2011, p. 15-27.

${ }^{31}$ Nesse sentido, MARQUES NETO, Francisco de Azevedo. Público e Privado no Setor de Saúde. In: Revista de Direito Público da Economia, ano 3, nº 9, p. 112, jan./mar. 2005.

${ }^{32}$ FIGUEIREDO, Leonardo Viseu. Curso de Direito de Saúde Suplementar - Manual Jurídico de Planos e Seguros de Saúde. 2. ed., Gen/Forense: Rio de Janeiro, 2012, p. 19-20.

${ }^{33}$ DJe no 228 , de 19 de novembro de 2014. 
de que na relação jurídica mantida entre operadoras de planos de saúde e de seguros privados de saúde e os indivíduos que a eles aderem incidirem normas destinadas "a proteger a parte hipossuficiente da relação jurídica". Essas normas são a Lei 9.656/98 e, para os contratos a ela anteriores, o Código de Defesa do Consumidor e, antes mesmo deste, também os princípios gerais de direito, como a boa fé, a proteção da parte hipossuficiente da relação jurídica e a vedação ao abuso de direito, "descabendo falar em direito adquirido à atuação em mercado ausente de fiscalização do poder público" (trechos transcritos do voto do Ministro Marco Aurélio). Ou seja, mesmo quando prestada por particulares, com intuito lucrativo, há incidência de normas de proteção à parte mais frágil da relação.

Destaque-se que a afirmação de um setor privado na saúde, no Brasil, se deu de forma complexa e com uma interface às vezes contraditória com o setor público ${ }^{34}$, o que torna necessário examinar, ainda que brevemente, essas relações.

Durante os anos 1930, na era Vargas, se pavimentou o caminho para o modelo atual, baseado na intervenção do Estado, que na época se dava por meio da prestação de serviços de saúde, com graus variáveis de cobertura, ofertada aos empregados de determinadas categorias profissionais por meio de seus institutos de aposentadorias e pensões ${ }^{35}$. Trabalhadores por conta própria tinham uma reduzida cobertura por parte do serviço público ou de hospitais filantrópicos ou da iniciativa privada.

Com o Regime Militar, a partir de 1964, há, por um lado, uma expansão da proteção social pública, por meio da incorporação dos trabalhadores rurais ao sistema, e, por outro, a expansão de serviços privados de saúde, muitas vezes custeada por recursos públicos, a exemplo da reforma e construção de hospitais privados com recursos do orçamento, o que levou à expansão dos planos privados de saúde ${ }^{36}$. Nos anos 1980 , a recessão econômica, que conduziu a problemas de financiamento no campo da proteção social, aliada à gradual abertura política, levaram ao surgimento do Movimento Sanitário Brasileiro, integrado por professores da área de Saúde Pública, membros da Sociedade Brasileira para o Progresso da Ciência e por profissionais da saúde, com ligações variadas com sindicatos e movimentos sociais, e à afirmação da necessidade de reformar o sistema de saúde, visto não mais como apenas um problema biológico, resolvido pelo oferecimento de serviços

\footnotetext{
${ }^{34}$ Para uma visão histórica dessa relação, examinar PAIM, Jairnilson; TRAVASSOS, Cláudia; ALMEIDA, Célia; BAHIA, Lígia; MACINKO, James. The Brazilian health System: history, advances and challenges. In: The Lancet, vol. 377, maio 2011, p. 1778-1797.

${ }^{35}$ PAIM, Jairnilson; TRAVASSOS, Cláudia; ALMEIDA, Célia; BAHIA, Lígia; MACINKO, James. The Brazilian health System: history, advances and challenges. In: The Lancet, vol. 377, maio 2011, p. 1781.

${ }^{36}$ PAIM, Jairnilson; TRAVASSOS, Cláudia; ALMEIDA, Célia; BAHIA, Lígia; MACINKO, James. The Brazilian health System: history, advances and challenges. In: The Lancet, vol. 377, maio 2011 , p. $1783-1784$.
} 
médicos, mas como uma questão política e social ${ }^{37}$. O marco de tal movimento foi a $8^{a}$ Conferência Nacional de Saúde, realizada em 1986, em que se aprovou o entendimento de que a saúde é um direito do indivíduo, se lançaram as bases do futuro Sistema Único de Saúde - SUS e se desenvolveram as estratégias de cooperação entre as unidades federadas, que hoje marcam o sistema $^{38}$. Tais pontos de vista foram adotados pela Assembleia Nacional Constituinte e se materializaram na Constituição de 1988, não sem resistência de um cada vez mais organizado setor privado, o qual também experimentou crescimento e realizou investimentos mirando nos novos potenciais clientes. A Constituição foi promulgada em uma época de instabilidade econômica e de mudanças políticas, com o enfraquecimento dos movimentos sociais e do ideário estatizante e o avanço do chamado neoliberalismo.

O sistema de saúde brasileiro se mostra atualmente como um "mix" público-privado, em que se identificam: a) o SUS, financiado pelo Estado nos planos municipal, estadual e federal, incluindo os serviços militares; b) o setor privado, lucrativo e não lucrativo, financiado por uma diversidade de fontes, públicas (pense-se nos planos de saúde contratados por entidades estatais para atender seus servidores) e privadas; c) o setor de seguros de saúde, com diferenciados tipos de planos, prêmios e subsídios fiscais ${ }^{39}$. O subsistema privado mantém pontos de contato com o sistema público. Fornece serviços ao próprio SUS, por meio de contratos. Muitos hospitais privados atendem pacientes pelo SUS e também a pessoas que têm planos e seguros de saúde. Inúmeros profissionais de saúde trabalham para o SUS e também atendem de forma particular ou a planos e seguros ${ }^{40}$. Serviços privados de saúde que atendem também pelo SUS recebem do Estado por esse atendimento. Pessoas que possuem planos de saúde podem também ser atendidas pelo SUS e o próprio Estado acaba subsidiando o sistema privado na medida em que permite a dedução da base de cálculo do imposto de renda dos valores pagos a prestadores privados. Isso gera constantes reclamações dos defensores do sistema público de saúde, que demandam mais recursos para o SUS e que se busque limitar o espaço do setor privado.

\footnotetext{
${ }^{37}$ PAIM, Jairnilson; TRAVASSOS, Cláudia; ALMEIDA, Célia; BAHIA, Lígia; MACINKO, James. The Brazilian health System: history, advances and challenges. In: The Lancet, vol. 377, maio 2011, p. 1784.

${ }_{38}$ PAIM, Jairnilson; TRAVASSOS, Cláudia; ALMEIDA, Célia; BAHIA, Lígia; MACINKO, James. The Brazilian health System: history, advances and challenges. In: The Lancet, vol. 377, maio 2011 , p. 1785.

39 PAIM, Jairnilson; TRAVASSOS, Cláudia; ALMEIDA, Célia; BAHIA, Lígia; MACINKO, James. The Brazilian health System: history, advances and challenges. In: The Lancet, vol. 377, maio 2011 p. 1785.

${ }_{40}$ VICTORA, César; BARRETO, Maurício; LEAL, Maria; MONTEIRO, Carlos; SCHMIDT, Maria; PAIM, Jairnilson; BASTOS, Francisco; ALMEIDA, Célia; BAHIA, Lígia; TRAVASSOS, Cláudia; REICHENHEIM, Michael; BARROS, Fernando e The Lancet Brazil series Working Group. Health Conditions and Health-policy Innovations in Brazil: the way forward. In: The Lancet, vol. 377, maio 2011, p. 2045.
} 
Existem no Brasil pouco mais de mil operadoras de planos de saúde ${ }^{41}$, a maioria de pequeno porte e com atuação local. O mercado é concentrado, já que apenas oito operadoras - $8,2 \%$ do total - fornecem serviços para $80,3 \%$ dos clientes. Na região sudeste do Brasil se concentram $61,5 \%$ das operadoras e $65,5 \%$ de todos os contratos mantidos ${ }^{42}$. Entre 2002 e 2008 mais de seis milhões de brasileiros ingressaram no sistema privado de saúde, sendo que a proporção da população coberta por tal sistema tem se mantido constante em torno de $25 \%{ }^{43}$. Ou seja, alcança por volta de cinquenta milhões de brasileiros.

A necessidade de submeter a saúde privada à regulação pública se justifica ante os seguintes fundamentos, adaptados a partir de estudo de Amadeu Carvalhaes Ribeiro acerca da atividade seguradora ${ }^{44}$ : a) manutenção da higidez econômico-financeira das operadoras; b) proteção à livre concorrência e à livre iniciativa; c) proteção do consumidor. No caso das operadoras de planos de saúde e de seguros de saúde a regulação é exercida pelo Conselho Nacional de Saúde Suplementar e a fiscalização pela Agência Nacional de Saúde Suplementar.

Deve-se levar em conta que os contratos dos chamados planos de saúde são elaborados com base em cálculos atuariais e a intervenção em seus termos, especialmente na equação que inclui custos e serviços cobertos pode fragilizar a garantia da oferta de "atendimento eficiente e eficaz"45.

Não se pode pretender impor preços incompatíveis sob risco de comprometer a saúde financeira do prestador de serviço e ainda a de haver queda da qualidade do serviço. Ademais, não se pode impor aos planos privados o atendimento de pessoas sem recursos, já que incumbe ao Estado tal papel de atender os hipossuficientes. A qualidade técnica da prestação do serviço, visando tutelar efetivamente a saúde, também constitui vetor valorativo a ser considerado na fiscalização e regulamentação efetuada pelo Estado.

Verifica-se, portanto, que há um forte papel dirigista desempenhado pelo poder público, no tocante à saúde suplementar, decorrência imediata da sua

\footnotetext{
${ }^{41} 1017$ conforme dados de 2010 indicados por PAIM, Jairnilson; TRAVASSOS, Cláudia; ALMEIDA, Célia; BAHIA, Lígia; MACINKO, James. The Brazilian health System: history, advances and challenges. In: The Lancet, vol. 377, maio 2011, p. 1786.

${ }_{42}$ PAIM, Jairnilson; TRAVASSOS, Cláudia; ALMEIDA, Célia; BAHIA, Lígia; MACINKO, James. The Brazilian health System: history, advances and challenges. In: The Lancet, vol. 377, maio 2011, p. 1786.

${ }^{43}$ VICTORA, César; BARRETO, Maurício; LEAL, Maria; MONTEIRO, Carlos; SCHMIDT, Maria; PAIM, Jairnilson; BASTOS, Francisco; ALMEIDA, Célia; BAHIA, Lígia; TRAVASSOS, Cláudia; REICHENHEIM, Michael; BARROS, Fernando e The Lancet Brazil series Working Group. Health Conditions and Health-policy Innovations in Brazil: the way forward. In: The Lancet, vol. 377, maio 2011, p. 2045.

${ }^{44}$ RIBEIRO, Amadeu Carvalhaes. Direito de Seguros - Resseguro, seguro direto e distribuição de serviços. Atlas: São Paulo, 2006, p. 137.

${ }^{45}$ FIGUEIREDO, Leonardo Viseu. Curso de Direito de Saúde Suplementar - Manual Jurídico de Planos e Seguros de Saúde. 2. ed., Gen/Forense: Rio de Janeiro, 2012, p. 20.
} 
vinculação ao princípio da dignidade da pessoa. Como destaca Leonardo Viseu Figueiredo $^{46}$, a:

"relação jurídica entre o operador de mercado e o consumidor (...) é fruto direto da celebração de um contrato de plano ou seguro privado de assistência à saúde. Todavia, a autonomia privada de vontades é limitada às previsões contidas na lei, devendo observar as cláusulas mínimas de prestação de serviços de saúde estabelecidas. Somente após a garantia do mínimo legal é que as partes contratantes podem negociar um plus nos serviços a serem disponibilizados".

Assim, deve-se considerar, ao procurar a intervenção estatal a posteriori nos contratos de planos de saúde, que esses contratos já são regulados a priori. A regulação, ao contrário da intervenção judicial, pode ser internalizada, conforme se verá adiante e, embora possa ser nociva, o é menos que a intervenção após a celebração do contrato, via de regra.

Assim, a Lei 9.656/98, que trata dos Planos de Saúde, e a Lei 9.961/2000, que trata do papel e das competências da Agência Nacional de Saúde Suplementar - ANS, bem como a regulamentação editada por esta última e pelo Executivo, impactam fortemente a liberdade de contratar e o conteúdo dos contratos celebrados entre operadoras e consumidores.

Durante os dois primeiros anos de vigência da Lei 9.656/98, houve uma atuação conjunta do Ministério da Fazenda, por meio da Superintendência de Seguros Privados - SUSEP, à qual competia efetuar a regulação econômica do setor, sobretudo, pelo estabelecimento de regras sobre o ingresso de novos prestadores de serviços, bem como sobre constituição e manutenção de garantias e provisões financeiras, e do Ministério da Saúde, por meio da Secretaria de Assistência à Saúde e do Departamento de Saúde Suplementar, que estabeleciam os critérios de qualidade a serem seguidos. Posteriormente, com a criação da Agência Nacional de Saúde Suplementar - ANS, referida agência assumiu a tarefa regulatória da saúde privada.

O instrumento pelo qual se viabiliza a prestação de serviços de saúde por entidades privadas é o contrato, denominado pela Lei 9.656/98, em seu art. ${ }^{\circ}$, inciso $\mathrm{I}$, de planos privados de assistência à saúde ${ }^{47}$. Como lembra a doutrina ${ }^{48}$,', porém, com o advento da Lei 10.185/2001, que submeteu à incidência da

\footnotetext{
${ }^{46}$ FIGUEIREDO, Leonardo Viseu. Curso de Direito de Saúde Suplementar - Manual Jurídico de Planos e Seguros de Saúde. 2. ed., Gen/Forense: Rio de Janeiro, 2012, p. 12.

${ }^{47}$ Assim conceituados: "prestação continuada de serviços ou cobertura de custos assistenciais a preço pré ou pós estabelecido, por prazo indeterminado, com a finalidade de garantir, sem limite financeiro, a assistência à saúde, pela faculdade de acesso e atendimento por profissionais ou serviços de saúde, livremente escolhidos, integrantes ou não de rede credenciada, contratada ou referenciada, visando a assistência médica, hospitalar e odontológica, a ser paga integral ou parcialmente às expensas da operadora contratada, mediante reembolso ou pagamento direto ao prestador, por conta e ordem do consumidor".

${ }^{48}$ RIBEIRO, Amadeu Carvalhaes. Direito de Seguros - Resseguro, seguro direto e distribuição de serviços. Atlas: São Paulo, 2006, p. 144.
} 
Lei 9.656/98 as seguradoras de saúde, cumpre distinguir entre contrato de plano privado de assistência à saúde e contrato de seguro-saúde.

No primeiro, o beneficiário se obriga ao pagamento de "contraprestação pecuniária e periódica, ainda que de forma indireta, sob forma de benefício salarial" 49 , enquanto a entidade se obriga a "disponibilizar atendimento em rede médica específica, bem como a arcar com o ônus financeiro, tão somente, nas hipóteses em que ocorram eventuais enfermidades contratualmente cobertas" ${ }^{\prime 50}$. Tal contrato se caracteriza por ser bilateral (podendo ser multilateral nos planos coletivos), de trato sucessivo e prazo indeterminado (a legislação somente admite a rescisão unilateral por parte dos beneficiários, sendo que a operadora somente pode rescindir a avença nas hipóteses permitidas pela ANS, conforme previsão legal, por fraude ou inadimplência superior a sessenta dias, observado o devido processo legal), oneroso, comutativo, de adesão e aleatório ${ }^{51}$.

Já o contrato de seguro-saúde se caracteriza por ser uma modalidade de transferência do risco, pela qual a seguradora se obriga contratualmente a "indenizar o segurado na hipótese de ocorrência de fatos danosos à vida, à saúde, aos direitos ou ao patrimônio do segurado" ${ }^{, 52}$. Trata-se, portanto, de uma modalidade de contrato de seguro, definida pelo Código Civil, em seu art. 757, como aquele em que "o segurador se obriga, mediante pagamento do prêmio, a garantir interesse legítimo do segurado, relativo a pessoa ou a coisa, contra riscos predeterminados". Como o risco de adoecimento ou afetação da saúde do segurado e/ou de seus dependentes constitui um evento aleatório como outro qualquer, nesse contrato ele é transferido, de forma onerosa e contratual, à seguradora, "mediante a prestação de assistência médico-hospitalar por meio de entidades 'conveniadas' ou do reembolso das despesas"53. Tal forma de seguro já havia sido prevista no Decreto-Lei 73/1966, que tratava sobre o Sistema Nacional de Seguros Privados, em seus arts. 129 e 130. Como lembra Leonardo Viseu Figueiredo ${ }^{54}$, a Lei 9.656/98:

"deu nova disciplina à suplementação privada de serviços de saúde, obrigando a adaptação dos então vigentes seguros-saúde às suas regras

\footnotetext{
${ }^{49}$ FIGUEIREDO, Leonardo Viseu. Curso de Direito de Saúde Suplementar - Manual Jurídico de Planos e Seguros de Saúde. 2. ed., Gen/Forense: Rio de Janeiro, 2012, p. 167.

${ }^{50}$ FIGUEIREDO, Leonardo Viseu. Curso de Direito de Saúde Suplementar - Manual Jurídico de Planos e Seguros de Saúde. 2. ed., Gen/Forense: Rio de Janeiro, 2012, p. 167.

${ }^{51}$ Acerca das características do contrato de seguro, examinar TIMM, Luciano Benetti; ALVES, Francisco Kümmel. (Custos de Transação no Contrato de Seguro: proteger o segurado é socialmente desejável?. In: Revista de Direito Público da Economia, ano 5, nº 19, jul./set. 2007, p. 136).

${ }^{52}$ FIGUEIREDO, Leonardo Viseu. Curso de Direito de Saúde Suplementar - Manual Jurídico de Planos e Seguros de Saúde. 2. ed., Gen/Forense: Rio de Janeiro, 2012, p. 169.

${ }^{53}$ FIGUEIREDO, Leonardo Viseu. Curso de Direito de Saúde Suplementar - Manual Jurídico de Planos e Seguros de Saúde. 2. ed., Gen/Forense: Rio de Janeiro, 2012, p. 169.

${ }^{54}$ Curso de Direito de Saúde Suplementar - Manual Jurídico de Planos e Seguros de Saúde. 2. ed., Gen/Forense: Rio de Janeiro, 2012, p. 170.
} 
estabelecidas para os planos de saúde, fato que tornou os referidos contratos muito semelhantes. Todavia, em que pese ter como objeto a prestação de procedimentos médicos, o seguro-saúde é, na sua essência, um contrato securitário, com características econômico-financeiras que Ihes são próprias".

Uma observação final, para se compreender a estrutura do contrato de plano de saúde privado, diz respeito à forma de financiamento. A função social do contrato limita a liberdade contratual, por expressa determinação do art. 421 do Código Civil. Busca evitar desequilíbrio entre as partes e propiciar a consecução de objetivos de interesse da sociedade, porém, por se tratar de princípio vago e de conteúdo determinado de maneira subjetiva, pode, se interpretado de maneira irresponsável, causar prejuízos ao mercado de maneira geral. Diferentemente da previdência privada complementar, que adota como modelo básico o regime de capitalização ${ }^{55}$, em que há a formação de um fundo individualizado mediante aportes do participante e eventualmente de um terceiro, o patrocinador, sendo o benefício final pago em função do total amealhado, acrescido de rendimentos obtidos com sua administração, o contrato de plano de saúde privado adota o modelo da repartição simples ou mutualismo.

Sobre o tema, Leonardo Viseu Figueiredo afirma ${ }^{56}$ :

"o sistema de repartição simples se baseia na reunião de um grande número de expostos aos mesmos riscos possibilitando estabelecer o equilíbrio aproximado entre as prestações dos consumidores e as contraprestações das operadoras de planos de saúde. Assim, ocorrendo um sinistro, este é absorvido pela massa de consumidores”. (...)“A lógica do sistema não é uma opção da operadora, mas uma exigência de funcionamento do próprio segmento econômico. Se ao revés da repartição simples adotássemos o sistema de capitalização, os consumidores de planos de saúde, quando da ocorrência do sinistro, somente poderiam gastar o que tivessem poupado, fato que por si só já se evidencia absurdo".

Compreendendo-se a lógica da formação dos fundos de reserva, pode-se claramente visualizar o perigo de intervenções irresponsáveis nos plano: os cálculos atuariais levam em conta o risco assumido e o histórico de sinistros do grupo, além de fatores como a regulação e a inadimplência.

\footnotetext{
${ }^{55}$ A capitalização é adotada, na previdência complementar, sobretudo a fechada, para os benefícios programados, sendo possível adotar a repartição simples no tocante aos benefícios de risco ou não programados, como os decorrentes de invalidez ou morte. Para esses últimos, o montante acumulado não se mostrará muitas vezes suficiente para fazer face aos compromissos previstos. Daí porque parcela da contribuição dos participantes e do patrocinador pode ser destinada à cobertura de tais benefícios de risco. A propósito, verificar o teor do $\S 1^{\circ}$ do art. 18 da Lei Complementar 109/2001.

${ }^{56}$ Curso de Direito de Saúde Suplementar - Manual Jurídico de Planos e Seguros de Saúde. 2. ed., Gen/Forense: Rio de Janeiro, 2012, p. 156.
} 
Quando qualquer outro fator não considerado intervém (como é o caso do Poder Judiciário), pode ocorrer desequilíbrio e comprometimento da prestação de serviços aos usuários.

A despeito de se tratar de um instrumento de direito privado, o contrato é afetado por disposições de ordem pública, cogentes, decorrentes da Lei 9.656/98, como, por exemplo, as que fixam um rol mínimo de procedimentos médicos que todos os contratos devem ofertar e cobrir para seus beneficiários, a garantia de atendimento mesmo em caso de inadimplência contratual, vedação à exclusão de coberturas a doenças preexistentes, períodos máximos de carência legalmente fixados, vedação ao tratamento discriminatório entre os consumidores, em razão de idade ou deficiência física ${ }^{57}$.

\section{A SAÚDE PRIVADA NO BRASIL E OS RISCOS DE UMA INADEQUADA INTERVENÇÃO JUDICIAL}

Apresentados os traços principais da organização da saúde privada suplementar no Brasil, cumpre destacar os riscos para o sistema decorrentes de uma inadequada atuação do Poder Judiciário.

Aparentemente, existe a crença no Brasil de que incumbe à regulação estatal buscar o equilíbrio entre as posições dos operadores de planos de saúde e dos consumidores. Não raro, o próprio ente regulador altera, por exemplo, o rol mínimo de serviços destinados aos beneficiários, visando atualizá-los e garantir de forma mais efetiva o direito à saúde. Havendo impacto no custo da prestação do serviço, devidamente comprovado, pode caber revisão dos valores cobrados ${ }^{58}$.

Ressalte-se que, para melhor entendimento, a regulação dos contratos de plano de saúde por parte, tando do Poder Legislativo, quanto dos órgãos reguladores pode ser considerada uma externalidade. Entende-se por externalidade os efeitos causados por decisões sobre pessoas e entes que dela não participaram. Assim, quando o poder legislativo ou a autoridade reguladora cria ou modifica uma norma, os efeitos dessa decisão são claramente sentidos pelos regulados. Via de regra, no caso das operadoras de planos de saúde, essas externalidades são negativas, ou seja, criam mais custos na operação dos planos.

Quando as externalidades ocorrem antes do oferecimento de um serviço, elas podem ser internalizadas, ou seja, o empresário pode transferir esse

\footnotetext{
${ }^{57}$ FIGUEIREDO, Leonardo Viseu. Curso de Direito de Saúde Suplementar - Manual Jurídico de Planos e Seguros de Saúde. 2. ed., Gen/Forense: Rio de Janeiro, 2012, p. 157.

${ }^{58}$ Nesse sentido, examinar FIGUEIREDO, Leonardo Viseu (Curso de Direito de Saúde Suplementar - Manual Jurídico de Planos e Seguros de Saúde. 2. ed., Gen/Forense: Rio de Janeiro, 2012, p. 247 e seguintes, especialmente p. 254), que distingue o reajuste linear, por variação dos custos, o reajuste por mudança de faixa etária, decorrente da mudança do risco atuarial de sinistralidade, ligado ao perfil pessoal de cada beneficiário, e o reajuste por revisão técnica, decorrente da teoria da imprevisão, que se funda em acontecimentos imprevisíveis que alteram o equilíbrio financeiro e atuarial. Todos devem observar limites e regras fixados pela legislação e pela ANS.
} 
acréscimo de custo ao beneficiário do plano. Quando, todavia, as externalidades vêm após a existência do contrato e por força de lei se Ihes aplicam, não há como essa externalidade ser internalizada de maneira adequada.

Essa internalização não adequada gera o que se chama risco moral e seleção adversa. O risco moral diz respeito ao comportamento das pessoas que, ao contratar determinada apólice de seguro, por exemplo, deixam de tomar os cuidados necessários com o bem protegido. Ou quando se contrata um plano de saúde, passa-se a usá-lo sem necessidade, ou ainda quando, ao contratar determinado limite de cobertura, entendem que podem usá-lo apelando à justiça.

O risco moral acaba por gerar a seleção adversa. A seleção adversa ocorre quando determinado mercado, por internalizar custos indefinidos, por conta de insegurança institucional e jurídica, ou informação assimétrica, acaba por cobrar um preço tão alto, que os "bons" usuários não estão dispostos a pagar. Por outro lado, os "maus" usuários pagam o preço ou por que não estão dispostos a cumprir os contratos, ou mesmo por que pretendem buscar por meio do Judiciário cobertura para as quais não teriam direito se observassem seus contratos. Esse ciclo gera, de um lado, preços altos e, de outro, maus serviços.

Assim, a insegurança jurídica eleva os custos de qualquer mercado. Não é diferente com os planos de saúde. Neste trabalho, serão tratados especificamente as externalidades criadas pelo Poder Judiciário.

Importa, assim, considerar, para os fins deste trabalho, o impacto decorrente de decisões judiciais e as externalidades de acarretam. Alguns economistas dedicam-se ao estudo do Poder Judiciário e ao impacto de suas decisões em determinados mercados, um dos mais destacados, Armando Castelar Pinheiro ${ }^{59}$, afirma que:

"No Brasil, as deficiências do judiciário, decorrentes de seu perfil institucional e de sua estrutura administrativa, se vêem acentuadas pela instabilidade do quadro legal do país, pelo arcaísmo e excessivo formalismo dos códigos de processo, pela má formação de juizes e funcionários, entre outros fatores."

Mais adiante, o autor trata de como as instituições judiciais, mais especificamente o Poder Judiciário, interferem e até determinam o "ritmo e a forma do desenvolvimento econômico dos países"

O papel das instituições nas economias e crescimento de mercados foi objeto da obra clássica de Douglas North. Afirma o autor, ganhador do premio Nobel de Economia em 1993, que:

\footnotetext{
${ }^{59}$ PINHEIRO, Armando Castelar (org.) Judiciário e Economia do Brasil. São Paulo: Sumará, 2000 , p. 13.

${ }^{60}$ PINHEIRO, Armando Castelar (org.) Judiciário e Economia do Brasil. São Paulo: Sumará, 2000, p. 14.
} 
"a dificuldade em se criar um sistema judicial dotado de relativa imparcialidade, que garanta o cumprimento de acordos, tem-se mostrado um impedimento crítico no caminho do desenvolvimento econômico no mundo ocidental, a evolução dos tribunais, dos sistemas legais e de um sistema judicial relativamente imparcial tem desempenhado um papel preponderante no desenvolvimento de um complexo sistema de contratos capaz de se estender no tempo e no espaço, um requisito essencial para a especialização econômica". ${ }^{61}$

Os pontos críticos levantados por North apresentam-se, em grande conta, como o cerne da discussão: imparcialidade e cumprimento de acordos. Assim, a interferência do Estado, por meio do Poder Judiciário em acordos previamente firmados entre as partes, obedecidas as "regras do jogo" estabelecidas previamente, pode se configurar em um aspecto inibidor do crescimento econômico, motivo por que deve ser excepcional, e baseado em premissas claras e objetivas.

A doutrina cita, por exemplo, a condenação de planos de saúde a prestar serviços não previstos contratualmente ou a fornecer medicamentos não constantes de seus catálogos ${ }^{62}$. No RESP 668.216/SP, por exemplo, o STJ, aplicando o Código de Defesa do Consumidor, considerou abusiva cláusula que não prevê método ou terapia mais moderno para tratamento de uma doença. No caso, se entendeu que se a patologia (câncer) está coberta, mas não se menciona uma determinada terapia (tratamento ambulatorial e quimioterapia), o seguro-saúde deve ofertar o tratamento mais moderno. A decisão recorrida havia considerado a cláusula contratual limitativa legal e não abusiva. Já o STJ, sem desconsiderar que, além de se proteger o consumidor, deve haver uma preocupação com a viabilidade dos planos de saúde, entendeu que se deve distinguir entre a patologia e as terapias. Se o plano cobre a patologia, não pode excluir os possíveis tratamentos, pois se assim o fizesse estaria substituindo a decisão do especialista médico, que é a que deve prevalecer, sob pena de por em risco a vida do consumidor.

A referida decisão não considerou o custo acrescido, para o plano e para os demais participantes, que a inclusão ilimitada de novas terapias pode acarretar. E, apesar de aludir à decisão do especialista médico, não fixou como parâmetro a comprovação da eficácia terapêutica da medida buscada judicialmente. Como será visto, a medicina baseada em evidências busca privilegiar a eficácia e eficiência de um tratamento à autoridade do profissional da área médica, que, muitas vezes, pode vir a sugerir um tratamento que não se ampara na melhor prova científica ou que é mesmo desprovido de tal embasamento.

\footnotetext{
${ }^{61}$ NORTH, Douglas. Transaction Costs, Institutions and Economic Performance. International Center for Economic Growth, Occasional Paper n ${ }^{\circ}$ 30. San Francisco: ICS Press, 1992, p. 8.

${ }^{62}$ DIAS DE CASTRO, José Augusto. A Questão do Direito Fundamental à Saúde sob a Ótica da Análise Econômica do Direito. In: Revista de Direito Público da Economia, ano 6, $\mathrm{n}^{\circ}$ 21, jan./mar. 2008, p. 157.
} 
Ora, não se pode desconsiderar que o seguro se fundamenta em uma análise estatística, buscando equacionar o risco e distribuí-lo no interior do grupo a ele submetido dentro das possibilidades de sua ocorrência no futuro. Importante ainda ressaltar que os custos considerados referem-se à época contratada e às terapias existentes. Uma eventual internalização de custos indefinidos pode encarecer excessivamente os contratos e sua não-internalização pode comprometer a solvabilidade das operadoras.

Obrigar a cobertura de eventos não previstos originariamente ignora essa perspectiva, podendo levar ao desequilíbrio da relação contratual e acarretar um custo que será pago pelos demais integrantes do grupo que utilizam o contrato na forma prevista originariamente ${ }^{63}$. Os instrumentos contratuais são não apenas acordos de vontade que criam, modificam ou extinguem direitos. Eles contribuem para uma maior eficiência na alocação de recursos na medida em que estabelecem um padrão de conduta, reduzindo custos pela fixação de determinadas expectativas entre as partes ${ }^{64}$. Tal se mostra a função do contrato em economias de mercado, propiciando segurança jurídica à atividade empresarial e ainda a possibilidade de as partes alocarem recursos da maneira mais livre possível.

$\mathrm{Na}$ organização do negócio, a seguradora reúne pessoas que tenham riscos homogêneos e forma provisões suficientes para fazer face a esse risco, de acordo com a probabilidade estatística de sua ocorrência e uma análise atuarial pela qual se fixa o "valor médio" para cobrir o prejuízo total, a ser dividido entre os integrantes do grupo ${ }^{65}$.

Decisões judiciais que não atentem para essa realidade subjacente ao contrato de seguro e adotem uma abordagem excessivamente "solidarista"66, focada no caso concreto e sem considerar com rigor as circunstâncias da causa e seus efeitos em uma dimensão mais ampla, podem trazer prejuízos para a coletividade e para o universo composto pelos demais segurados.

\footnotetext{
63 TIMM, Luciano Benetti; ALVES, Francisco Kümmel. Custos de Transação no Contrato de Seguro: proteger o segurado é socialmente desejável?. In: Revista de Direito Público da Economia, ano $5, n^{\circ} 19$, jul./set. 2007, p. 126.

${ }^{64}$ TIMM, Luciano Benetti; ALVES, Francisco Kümmel. Custos de Transação no Contrato de Seguro: proteger o segurado é socialmente desejável?. In: Revista de Direito Público da Economia, ano $5, n^{\circ} 19$, jul./set. 2007, p. 131.

65 TIMM, Luciano Benetti; ALVES, Francisco Kümmel. Custos de Transação no Contrato de Seguro: proteger o segurado é socialmente desejável?. In: Revista de Direito Público da Economia, ano $5, n^{\circ} 19$, jul./set. 2007, p. 134-135.

${ }^{66}$ Por solidarismo jurídico, que se manifestaria na previsão do art. 421 do Código Civil, e que teria como precursor Émile Durkheim, se entende a perspectiva que defende que a análise jurídica não deve partir do direito subjetivo da pessoa mas da função que aquele direito exerce na sociedade. Busca alcançar um equilíbrio entre interesses em conflito pela distribuição equitativa dos ônus e dos lucros sociais, papel que caberia ao Estado. Este se substituiria ao mercado criando mecanismos que distribuiriam os benefícios sociais. Nesse sentido, TIMM, Luciano Benetti; ALVES, Francisco Kümmel. Custos de Transação no Contrato de Seguro: proteger o segurado é socialmente desejável? In: Revista de Direito Público da Economia, ano 5, no 19, jul./set. 2007, p. 142-143.
} 
Luciano Benetti Timm e Francisco Kümmel Alves, a propósito, analisam comparativamente uma decisão judicial proferida nos Estados Unidos e outras proferidas no Brasil, envolvendo ações contra seguradoras e prejuízos ou riscos não cobertos contratualmente ${ }^{67}$. $\mathrm{Na}$ decisão norte-americana, exarada no Estado do Mississipi, um casal postulou o pagamento de indenização por danos decorrentes de inundação subsequente ao furacão Katrina, a qual foi negada porque o contrato apenas previa indenização para danos decorrentes de ventos fortes ${ }^{68}$. Como havia exclusão de cobertura no caso de danos provenientes de uma ação combinada entre o vento e a água, o juiz do caso negou o pedido de indenização. $O$ caso criou um precedente que orientou novas decisões, gerando maior previsibilidade para as seguradoras e evitando a perspectiva de terem de encerrar suas atividades pelo pagamento de indenizações milionárias não cobertas contratualmente. O juízo se limitou a verificar a causa do dano e se a seguradora estaria ou não obrigada a indenizá-lo, sem efetuar considerações sobre a função social do contrato, a hipossuficiência da parte, cláusulas abusivas ou domínio econômico da seguradora $^{69}$.

Já as decisões brasileiras, por outro lado, proferidas pelo Tribunal de Justiça do Estado do Rio Grande do $\mathrm{Sul}^{70}$, reconheceram o direito a indenização por prejuízos não previstos contratualmente, fundando-se em uma interpretação ampliativa dos termos contratuais, motivadas talvez por um anseio de aplicar justiça ao caso, sem considerar, porém, suas circunstâncias e os efeitos globais da decisão, para o universo de beneficiários. Isso, conforme já se explicitou, causa elevação de preços e seleção adversa.

Uma observação, porém, se faz necessária. Muitas vezes, as alegações de desequilíbrio financeiro não se fazem acompanhar da devida comprovação. Assim, mostra-se necessária a demonstração, pelo plano ou seguro-saúde, de que a decisão contra a qual se insurge afeta o equilíbrio econômico da relação mantida com o beneficiário. Nesse sentido, em caso envolvendo pedido de revisão de benefício movido contra entidade de previdência complementar, o Superior Tribunal de Justiça, no RESP 1.244.810/RS, anulou sentença em processo em que havia sido pleiteada perícia atuarial, a fim de que fosse realizada a prova técnica que pudesse demonstrar a compatibilidade do pedido de revisão com o equilíbrio financeiro e atuarial da entidade de previdência complementar.

\footnotetext{
${ }^{67}$ Custos de Transação no Contrato de Seguro: proteger o segurado é socialmente desejável?. In: Revista de Direito Público da Economia, ano 5, nº 19, jul./set. 2007, p. 139 e seguintes.

${ }^{68}$ Leonard vs Nationwide Mutual Insurance Co.

${ }^{69}$ TIMM, Luciano Benetti; ALVES, Francisco Kümmel. Custos de Transação no Contrato de Seguro: proteger o segurado é socialmente desejável?. In: Revista de Direito Público da Economia, ano 5, $n^{\circ} 19$, jul./set. 2007, p. 141-142. Os autores destacam, porém, que o precedente formado suscitou um debate sobre outras alternativas compensatórias dos efeitos do furacão que não onerassem as seguradoras, como o aperfeiçoamento de um sistema de empréstimos governamentais para as vítimas de desastres.

${ }^{70}$ Foram as Apelações Cíveis 70009803297, 71000634774 e 70012909503.
} 
A rigor, o que se deve procurar manter, é a equação inicial do contrato. Por óbvio que circunstâncias se alteram e a própria teoria econômica admite que os contratos de longa duração são incompletos. Todavia, o Poder Judiciário, se necessária sua intervenção, deveria atuar para restabelecer, e não modificar aquilo originariamente estipulado pelas partes. As situações apenas devem ser realmente alteradas quando a medida puder deixar alguém em uma situação melhor, sem que isso acarrete a piora na situação de outrem. Esse é o conceito de Pareto-Eficiente. ${ }^{71}$

\section{A MEDICINA BASEADA EM EVIDÊNCIAS E SUA UTILIZAÇÃO COMO FONTE DE CRITÉRIOS PARA A ATUAÇÃO DO JUDICIÁRIO}

Uma vez analisada a possível inadequação, sob a perspectiva da distribuição dos custos contratuais, de decisões judiciais que não atentem para a realidade econômica subjacente aos planos de saúde, cumpre examinar uma outra linha argumentativa, direcionada à busca de racionalidade da atuação do Poder Judiciário, que decorre da medicina baseada em evidências (MBE).

Propugnada por Archibald Leman Cochrane, um epidemiologista escocês, a medicina baseada em evidências científicas (MBE) é uma abordagem que busca substituir a autoridade individual do médico pela ciência na tomada de decisões em matéria de saúde. Ou seja, ao invés de ser o médico quem decide, por exemplo, com base em sua autoridade, que um tratamento é melhor, a decisão deve ser orientada por critérios científicos. Não que a autoridade do médico e a situação do paciente não sejam relevantes, mas se busca complementá-las com a análise científica da solução proposta. Como decidir bem se há milhares de artigos científicos editados todos os anos? Se a própria indústria farmacêutica financia artigos, muitas vezes para fazer prevalecer o entendimento de que os medicamentos por ela produzidos, mais caros, são melhores? Aí entra a atuação da MBE, em especial por meio da The Cochrane Collaboration ${ }^{72}$, que, no Brasil, encontra correspondência no Centro Cochrane do Brasil ${ }^{73}$. Como os recursos disponíveis serão sempre limitados, eles devem ser utilizados de forma a propiciar formas equitativas de atenção à saúde, que tenham sido consideradas efetivas por meio de avaliações científicas adequadamente construídas.

Desenvolvida principalmente a partir da década de 1990, facilitada pelos avanços na informática, a MBE visa reduzir a incerteza na tomada de decisões médicas, buscando integrar as evidências clínicas com a experiência

\footnotetext{
${ }^{71} \mathrm{O}$ conceito desenvolvido pelo economista Vilfredo Pareto ensina que "sempre que uma mudança na lei deixar alguém em uma situação melhor sem deixar ninguém em uma situação pior, a "Eficiência de Pareto exige que se mude a lei" (COOTER, Robert; ULEN, Thomas. Direito e Economia. 5. ed., Porto Alegre: Bookman, 2010, p. 208) Note-se que, aqui, a palavra lei é usada em sentido lato, aplicando-se, assim, a contratos e regulamentos.

${ }^{72}$ Examinar o sítio na internet da The Cochrane Collaboration, http://www.cochrane.org. A principal obra de Cochrane foi Effectiveness and Efficiency: Random Reflections on Health Services, publicada em 1972.

${ }^{73}$ Cujo sítio na internet é http://www.centrocochranedobrasil.org.br.
} 
dos médicos, reduzindo o risco de exposição do paciente a intervenções desnecessárias e muitas vezes de alto custo ${ }^{\dagger 4}$. Em especial, a MBE enfatiza a importância de ensaios clínicos randomizados, que disponibilizam informações mais confiáveis que outras formas de evidência.

"A Medicina Baseada em Evidências - ou em prova científica rigorosa tem, para nortear as tomadas de decisões sobre os cuidados em saúde, o compromisso da busca explícita e honesta das melhores evidências científicas da literatura médica"75. Para esse fim, são analisados os artigos científicos sobre um dado tratamento ou medicamento e agrupados de acordo com sua qualidade.

Os melhores artigos são os que examinam o maior número de pacientes, escolhidos ao acaso (randomicamente), comparando com quem não recebeu o tratamento ou medicamento (grupo de controle). Faz-se uma meta-análise, uma análise dos artigos científicos, agrupando-os a partir de sua qualidade e definindo qual é a orientação que deles decorre: se o tratamento é eficaz, se há alternativa mais barata ou se não são conclusivos, sendo necessários mais estudos. Tal meta-análise presta-se a orientar os médicos, os serviços públicos de saúde e os planos de saúde privados a escolher quais medicamentos ou tratamentos devem ser adotados.

A medicina baseada em evidências pode, assim, transformar-se em fonte de orientações para o exercício do controle jurisdicional em matéria de fornecimento de medicamentos ou tratamentos. Isso, em primeiro lugar, em virtude da ausência de conhecimento técnico específico por parte dos magistrados; em segundo lugar pela necessidade de evitar decisões amparadas exclusivamente na opinião de um único médico, o do paciente, sem considerar a eficácia e a eficiência do tratamento proposto e a existência de alternativas menos custosas.

Muitas decisões são proferidas, inclusive em sede antecipatória ou cautelar, sem considerar tais aspectos. Houve já hipótese de decisão proferida unicamente com base em notícia jornalística, determinando o fornecimento de medicamento ainda em fase de testes ${ }^{76}$. O próprio STF chegou a reconhecer

\footnotetext{
${ }^{74}$ CHEHUEN NETO, José Antônio; SIRIMARCO, Mauro Toledo; GUERRA, Magno Cunha de Souza; SOUZA E SILVA, Virgílio; PORTELA, Wélida Sales; ROCHA, Flávio Roberto Silva. Percepção da Aplicabilidade da Medicina Baseada em Evidência. HU Revista Universidade Federal de Juiz de Fora, v. 34, no 1, jan./mar. 2008, p. 34.

${ }^{75}$ ATALLAH, Álvaro Nagib; CASTRO, Aldemar Araújo. Medicina Baseada em Evidências: o elo entre a boa ciência e a boa prática. In: http://centrocochranedobrasil.org.br/cms/apl/artigos/artigo_517.pdf. Acesso em: 20 jan. 2014, p. V.

${ }^{76}$ DIAS DE CASTRO, José Augusto. A Questão do Direito Fundamental à Saúde sob a Ótica da Análise Econômica do Direito. In: Revista de Direito Público da Economia, ano 6, $\mathrm{n}^{\circ}$ 21, jan./mar. 2008 , p. 155. No caso, era o ENBREL, que custava quatro mil reais a caixa. Portaria do Ministério da Saúde recomendava a utilização de outro medicamento, o Infliximab, cuja eficácia era melhor demonstrada. O caso chegou ao STF, no Agravo Regimental em Recurso Extraordinário 271.286, que, no entanto, não levou em consideração os aspectos técnicos, mas apenas reconheceu o dever do Estado fornecer medicamentos a pessoa destituída de recursos ante a vinculação do direito à saúde ao direito à vida.
} 
o direito ao tratamento no exterior para a retinose pigmentar a despeito da inexistência de comprovação científica da eficácia da terapia buscada ${ }^{77}$.

A aplicação da medicina baseada em evidências consta de previsão legal expressa, na Lei 12.401/2011, que inseriu o Capítulo VIII ao Título II da Lei 8.080/90, que dispõe sobre as condições para a promoção, proteção e recuperação da saúde e a organização e funcionamento dos serviços correspondentes. Apesar de dizer respeito ao SUS, tal orientação mostra-se relevante também para os planos privados de saúde. Na própria dicção do artigo 19-Q da referida lei, conferem-se as atribuições para incorporar, excluir ou alterar novos medicamentos pelo SUS:

Art. 19-Q. A incorporação, a exclusão ou a alteração pelo SUS de novos medicamentos, produtos e procedimentos, bem como a constituição ou a alteração de protocolo clínico ou de diretriz terapêutica, são atribuições do Ministério da Saúde, assessorado pela Comissão Nacional de Incorporação de Tecnologias no SUS.

À Comissão Nacional de Incorporação de Tecnologias no SUS (CONITEC) incumbe elaborar relatório e decidir com base, necessariamente, nas "evidências científicas sobre a eficácia, a acurácia, a efetividade e a segurança do medicamento, produto ou procedimento objeto do processo, acatadas pelo órgão competente para o registro ou a autorização de uso" (inciso I do § $2^{\circ}$ do art. 19-Q da Lei 8.080/90). A Comissão também levará em conta a "avaliação econômica comparativa dos benefícios e dos custos em relação às tecnologias já incorporadas, inclusive no que se refere aos atendimentos domiciliar, ambulatorial ou hospitalar, quando cabível" (inciso II do $\S 2^{\circ}$ do art. 19-Q da Lei 8.080/90).

Os arts. 19-M, 19-N e 19-O, acrescentados pela Lei 12.401/2011, tratam sobre a dispensação de medicamentos e produtos de interesse da saúde, que devem observar diretrizes terapêuticas definidas em protocolo clínico para a doença ou agravo a ser tratado. Por protocolo clínico e diretriz terapêutica se entende, conforme previsão do inciso II do art. 19-N da Lei 8.080/90, o:

documento que estabelece critérios para o diagnóstico da doença ou do agravo à saúde; o tratamento preconizado, com os medicamentos e demais produtos apropriados, quando couber; as posologias recomendadas; os mecanismos de controle clínico; e o acompanhamento e a verificação dos resultados terapêuticos, a serem seguidos pelos gestores do SUS.

Conforme dispõe o art. 19-O da Lei 8.080/90, os protocolos clínicos e as diretrizes terapêuticas deverão:

estabelecer os medicamentos ou produtos necessários nas diferentes fases evolutivas da doença ou do agravo à saúde de que tratam, bem como aqueles indicados em casos de perda de eficácia e de surgimento

\footnotetext{
${ }^{77}$ RE 368564/DF, Relator Ministro Marco Aurélio, $1^{\text {a }}$ Turma, julgado em 13.04.2011.
} 
de intolerância ou reação adversa relevante, provocadas pelo medicamento, produto ou procedimento de primeira escolha.

O parágrafo único do art. $19-0$ da Lei 8.080/90 determina que, em "qualquer caso, os medicamentos ou produtos serão avaliados quanto à sua eficácia, segurança, efetividade e custo-efetividade para as diferentes fases evolutivas da doença ou do agravo à saúde de que trata o protocolo".

$\mathrm{Na}$ falta de protocolo clínico ou de diretriz terapêutica, a dispensação será realizada, conforme prevê o art. 19-P da Lei 8.080/2011:

I - com base nas relações de medicamentos instituídas pelo gestor federal do SUS, observadas as competências estabelecidas na Lei 8.080/90, e a responsabilidade pelo fornecimento será pactuada na Comissão Intergestores Tripartite;

II - no âmbito de cada Estado e do Distrito Federal, de forma suplementar, com base nas relações de medicamentos instituídas pelos gestores estaduais do SUS, e a responsabilidade pelo fornecimento será pactuada na Comissão Intergestores Bipartite;

III - no âmbito de cada Município, de forma suplementar, com base nas relações de medicamentos instituídas pelos gestores municipais do SUS, e a responsabilidade pelo fornecimento será pactuada no Conselho Municipal de Saúde.

Um caso de aplicação da legislação referente à incorporação de novas tecnologias se encontra, por exemplo, em Relatório da CONITEC acerca da incorporação da toxina botulínica para tratamento de bexiga hiperativa ${ }^{78}$. O relatório decorreu de pedido de incorporação formulado pelo laboratório fabricante do produto. A bexiga neurogênica, ou hiperativa, se caracteriza pela urgência em urinar, com ou sem incontinência, decorrente de alguma doença ou lesão que afete o cérebro, a medula espinhal ou os nervos que se dirigem à bexiga, seu esfíncter ou ambos.

Pode ocorrer em pacientes com algum tipo de paralisia, atingindo $16,5 \%$ da população adulta. O tratamento oferecido inclui fármacos conhecidos como anticolinérgicos, e também terapia comportamental, fisioterapia e cateterismo intermitente. A partir de alguns estudos, verificou-se que a toxina botulínica tipo A (BOTOX) também traz bons resultados no controle da bexiga hiperativa, sendo inclusive autorizado seu uso pela ANVISA.

O Ministério da Saúde, porém, com base no parecer da CONITEC, negou sua incorporação, com fundamento na ausência de definição da dose ideal. Reconheceu-se a eficácia do medicamento, mas se recomendou a realização de mais estudos, comparando com a medicação dispensada e buscando definir se sua incorporação pode ser benéfica para pacientes que não respondem à terapêutica adotada.

\footnotetext{
${ }^{78}$ O relatório pode ser consultado no sítio http://u.saude.gov.br/images/pdf/2014/janeiro/28/Toxina Botulinica-BexigaHieparativa-final.pdf. Acesso em: 24 out. 2014.
} 
Ou seja, mesmo contando um novo medicamente com autorização de uso já emitida pela Agência Nacional de Vigilância Sanitária - ANVISA, o Ministério da Saúde poderá negar sua incorporação com base não apenas em eventual dúvida acerca de sua segurança, efetividade, eficácia e acurácia, mas também a partir de considerações econômicas, ou seja, um balanço dos custos e dos benefícios decorrentes da nova tecnologia em relação às já incorporadas. Caso exista tratamento ou alternativa mais barata, no âmbito do SUS, que permita tratar da mesma condição, esta terá prioridade.

O art. 19-R da Lei 8.080/90 fixa que a incorporação, a exclusão e a alteração a que se refere o art. 19-Q do mesmo diploma serão efetuadas "mediante a instauração de processo administrativo, a ser concluído em prazo não superior a 180 (cento e oitenta) dias, contado a partir da data em que foi protocolado o pedido, sendo permitida a sua prorrogação por 90 (noventa) dias corridos, quando as circunstâncias exigirem". Os interessados na incorporação, normalmente fabricantes e laboratórios, deverão apresentar documentos e, se cabível, as amostras dos produtos que desejam ver incorporados. Haverá ainda consultas públicas que incluirão a divulgação do parecer emitido pela Comissão Nacional de Incorporação de Tecnologias no SUS. Caso a relevância da matéria o justifique, poderão ser realizadas também audiências públicas.

O art. 19-T da Lei 8.080/90, por sua vez, veda, em todas as esferas de gestão do SUS (União, Estados, Distrito Federal e Municípios) "o pagamento, o ressarcimento ou o reembolso de medicamento, produto e procedimento clínico ou cirúrgico experimental, ou de uso não autorizado pela ANVISA" (inciso I), bem como "a dispensação, o pagamento, o ressarcimento ou o reembolso de medicamento e produto, nacional ou importado, sem registro na mencionada agência" (inciso II).

Vê-se, portanto, que a adoção da medicina baseada em evidências pode conduzir a decisões melhor fundamentadas e dotadas de maior racionalidade, sob a perspectiva de seu custo para a sociedade, tanto no âmbito da Saúde Pública quanto na Saúde Privada, concretizando de forma adequada o direito fundamental à saúde. Obviamente, que, para tal, há de se considerar a situação específica do paciente e a opinião dos profissionais de saúde para se permitir os ajustes necessários a cada caso ${ }^{79}$. Eventualmente, a terapêutica prevista em protocolos clínicos e para a generalidade dos casos pode não servir para o paciente em questão ${ }^{80}$. Mas tal fato há de ser examinado adequadamente no processo, o que nem sempre ocorre.

\footnotetext{
${ }^{79}$ CHEHUEN NETO, José Antônio; SIRIMARCO, Mauro Toledo; GUERRA, Magno Cunha de Souza; SOUZA E SILVA, Virgílio; PORTELA, Wélida Sales; ROCHA, Flávio Roberto Silva. Percepção da Aplicabilidade da Medicina Baseada em Evidência. In: HU Revista Universidade Federal de Juiz de Fora, v. 34, $\mathrm{n}^{\circ}$ 1, jan./mar. 2008, p. 38.

${ }^{80}$ SNIDERMAN, Alan D.; LaCHAPELLE, Kevin J.; RACHON, Nikodem A.; FURBERB, Curt D. The Necessity for Clinical Reasoning in the Era of Evidence-Based Medicine. In: Mayo Clinic Proceedings, October 2013:88(10), p. 1110.
} 


\section{CONCLUSÕES}

Mesmo a utilização de parâmetros como a medicina baseada em evidências não prescinde da manutenção do equilíbrio contratual. Esse equilíbrio não deve ser determinado pelo juiz, que deve apenas, se necessária for sua intervenção, restabelecer o que originariamente foi contratado, para ambas as partes, de modo a não gerar externalidades negativas que se refletem em toda a sociedade. A medicina baseada em evidências, de toda a sorte, constitui uma abordagem que pode contribuir para uma maior racionalidade das decisões judiciais, por agregar à orientação do médico do autor considerações sobre a eficácia e a eficiência do procedimento ou medicamento buscado segundo a ciência médica. Para tal fim, as Recomendações 31, de 10 de março de 2010, e 36, de 12 de julho de 2011, do $\mathrm{CNJ}$, parecem apresentar diretrizes interessantes para um julgamento melhor fundado. Em especial, a busca de auxílio técnico específico para as questões clínicas colocadas pelas partes, por meio de convênio, a prévia oitiva dos gestores, antes da apreciação de medidas de urgência, e evitar autorizar o fornecimento de medicamentos não registrados pela ANVISA ou em fase experimental, salvo excessões previstas em lei. A criação de núcleos de apoio técnico ou câmaras técnicas, compostos por profissionais das áreas médica e farmacêutica, por exemplo, aos quais seriam encaminhadas cópias da petição inicial e documentos, permitiria o exame da controvérsia e o envio de informações sobre o registro do medicamento na ANVISA, sobre sua eficácia, acurácia e eficiência para tratar o autor, e sobre a existência de outro medicamento, de menor custo, que seja também eficaz, fornecido pelo SUS. No âmbito da saúde privada, merece referência a criação, pelo Tribunal de Justiça do Estado de São Paulo, de um Núcleo de Apoio Técnico e de Mediação ${ }^{81}$, que atua previamente à apreciação de tutelas de urgência, visando, inicialmente, obter uma composição amigável e, não sendo possível, subsidiar os magistrados com informações técnicas necessárias ao julgamento da lide.

\section{REFERÊNCIAS}

AICARDI, Nicola. La Sanità. In: CASSESE (Coord.). Trattato di Diritto Amministrativo: a cura di Sabino Cassese: diritto amministrativo speciale. 2. ed., v. 1, Milão: Giuffrè, 2003. p. 625-710.

ANDRADE, José Carlos Vieira de. O Direito ao Mínimo de Existência Condigna como Direito Fundamental a Prestações Estaduais Positivas: uma decisão singular do Tribunal Constitucional. Anotação ao Acórdão do Tribunal Constitucional n 509/02. Jurisprudência Constitucional, nº 1, p. 4-29, jan./mar. 2004.

ATALLAH, Álvaro Nagib; CASTRO, Aldemar Araújo. Medicina Baseada em Evidências: o elo entre a boa ciência e a boa prática. In: http://centrocochranedobrasil.org.br/cms/ apl/artigos/artigo_517.pdf. Acesso em: 20 jan. 2014.

AUBY, Jean-Marie. Le Droit de la Santé. Paris: Presses Universitaires de France, 1981.

\footnotetext{
${ }^{81}$ Notícia divulgada no sítio do Tribunal de Justiça do Estado de São Paulo em http://www.tjsp.jus.br/ institucional/canaiscomunicacao/noticias/Noticia.aspx?Id=26272. Acesso em: 12 jun. 2015.
} 
BERLINGUER, Giovanni. Bioética Cotidiana. Tradução Lavínia Bozzo Aguilar Porciúncula. Brasília: Editora da UNB, 2004.

CANOTILHO, J. J. Gomes. Direito Constitucional e Teoria da Constituição. 7. ed., Coimbra: Livraria Almedina, 2003.

CHEHUEN NETO, José Antônio; SIRIMARCO, Mauro Toledo; GUERRA, Magno Cunha de Souza; SOUZA E SILVA, Virgílio; PORTELA, Wélida Sales; ROCHA, Flávio Roberto Silva. Percepção da Aplicabilidade da Medicina Baseada em Evidência. HU Revista Universidade Federal de Juiz de Fora, v. 34, n² 1, jan./mar. 2008, p. 33-39.

COOTER, Robert; ULEN, Thomas. Direito e Economia. 5. ed., Porto Alegre: Bookman, 2010.

CORREIA, Sérvulo. Introdução ao Direito da Saúde. In: AAVV. Direito da Saúde e Bioética. Lisboa: Lex, 1991. p. 40-53.

DIAS DE CASTRO, José Augusto. A Questão do Direito Fundamental à Saúde sob a Ótica da Análise Econômica do Direito. In: Revista de Direito Público da Economia, ano $6, n^{\circ} 21$, p. 149-158, jan./mar. 2008.

DIAS, Eduardo Rocha. Autodeterminação Individual e Transplante de Órgãos: entre os direitos de personalidade e os direitos fundamentais. In: Joyceane Bezerra de Menezes (org.). Dimensões Jurídicas da Personalidade na Ordem Constitucional Brasileira. Florianópolis: Conceito Editorial, 2010, p. 129-165.

FERRANDO, Gilda. La Donazione dei Gameti in Prospetiva Bioética e nella Legge 40, alla Luce delle Recenti Pronunce Giurisprudenziali. In: Andrea Barenghi (org). Procreazione Assistita e Tutela della Persona. CEDAM: Milão, 2011, p. 15-27.

FIGUEIREDO, Leonardo Viseu. Curso de Direito de Saúde Suplementar - Manual Jurídico de Planos e Seguros de Saúde. 2. ed., Gen/Forense: Rio de Janeiro, 2012.

GOMES, Carla Amado. Defesa da Saúde Pública vs. Liberdade Individual: casos da vida de um médico de saúde pública. Lisboa: Associação Académica da Faculdade de Direito de Lisboa, 1999.

LAUBADÈRE, André de; VENEZIA, Jean-Claude. Traité de Droit Administratif. Paris: Libr. Generale de Droit e de Jurisprudence, 1993.

MARQUES NETO, Francisco de Azevedo. Público e Privado no Setor de Saúde. In: Revista de Direito Público da Economia, ano 3, nº 9, p. 105-154, jan./mar. 2005.

MILANEZ, Daniela. O Direito à Saúde: uma análise comparativa da intervenção judicial. Revista de Direito Administrativo, n 237, p. 197-221, jul./set. 2004.

NABAIS, José Casalta. O Dever Fundamental de Pagar Impostos. Coimbra: Livraria Almedina, 1998.

NORTH, Douglas. Transaction Costs, Institutions and Economic Performance. International Center for Economic Growth. Occasional Paper n 30. San Francisco: ICS Press, 1992. NOVAIS, Jorge Reis. As Restrições aos Direitos Fundamentais não Expressamente Autorizadas pela Constituição. Coimbra: Coimbra Editora, 2003.

NOVAIS, Jorge Reis. O Tribunal Constitucional e os Direitos Sociais - O Direito à Segurança Social. In: Direitos Fundamentais - Trunfos contra a Maioria. Coimbra: Coimbra Editora, 2006.

PAIM, Jairnilson; TRAVASSOS, Cláudia; ALMEIDA, Célia; BAHIA, Lígia; MACINKO, James. The Brazilian health System: history, advances and challenges. In: The Lancet, vol. 377, maio 2011, p. 1778-1797. 
PINHEIRO, Armando Castelar (org.) Judiciário e Economia do Brasil. São Paulo: Sumará, 2000.

PINHEIRO, Armando Castelar; SADDI, Jairo. Direito, Economia e Mercados. Rio de Janeiro: Campus, 2005.

RIBEIRO, Amadeu Carvalhaes. Direito de Seguros - Resseguro, seguro direto e distribuição de serviços. Atlas: São Paulo, 2006.

SARLET, Ingo Wolfgang. A Eficácia dos Direitos Fundamentais. 3. ed., Porto Alegre: Livraria do Advogado, 2003.

SARLET, Ingo Wolfgang. Algumas Considerações em Torno do Conteúdo, Eficácia e Efetividade do Direito à Saúde na Constituição de 1988. Interesse Público, v. 3, nº 12 , p. 91-107, out./dez. 2001.

SCAFF, Fernando Facury; NUNES, José Avelãs. Os Tribunais e o Direito à Saúde. Porto Alegre: Livraria do Advogado, 2011.

SNIDERMAN, Alan D.; LaCHAPELLE, Kevin J.; RACHON, Nikodem A.; FURBERB, Curt D. The Necessity for Clinical Reasoning in the Era of Evidence-Based Medicine. In: Mayo Clinic Proceedings, October 2013:88(10), p. 1108-1114.

TIMM, Luciano Benetti; ALVES, Francisco Kümmel. Custos de Transação no Contrato de Seguro: proteger o segurado é socialmente desejável?. In: Revista de Direito Público da Economia, ano 5, no 19, jul./set. 2007, p. 125-158.

VICTORA, César; BARRETO, Maurício; LEAL, Maria; MONTEIRO, Carlos; SCHMIDT, Maria; PAIM, Jairnilson; BASTOS, Francisco; ALMEIDA, Célia; BAHIA, Lígia; TRAVASSOS, Cláudia; REICHENHEIM, Michael; BARROS, Fernando e The Lancet Brazil series Working Group. Health Conditions and Health-policy Innovations in Brazil: the way forward. In: The Lancet, vol. 377, maio 2011, p. 2042-2053.

WANG, Daniel. A Escassez de Recursos como Limitação para Concretização de Direitos (Comentários a acórdão do STJ). In: Revista de Direito Público da Economia, ano 5, $\mathrm{n}^{0} 20$, out./nov. 2007, p. 239-254. 